NATIONAL LABORATORY

MANAGED BY UT-BATTELLE

FOR THE DEPARTMENT OF ENERGY

\title{
Advancing Residential Retrofits in the Mixed-humid Climate to Achieve Deep Energy Savings: Final Report on Knoxville, TN Homes
}

\section{October 2012}

Updated January 2013

\section{Prepared by}

Philip Boudreaux

Kaushik Biswas

Roderick Jackson

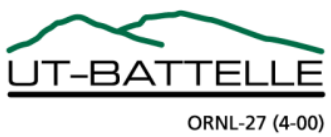




\section{DOCUMENT AVAILABILITY}

Reports produced after January 1, 1996, are generally available free via the U.S. Department of Energy (DOE) Information Bridge.

Web site http://www.osti.gov/bridge

Reports produced before January 1, 1996, may be purchased by members of the public from the following source.

National Technical Information Service

5285 Port Royal Road

Springfield, VA 22161

Telephone 703-605-6000 (1-800-553-6847)

TDD 703-487-4639

Fax 703-605-6900

E-mail info@ntis.gov

Web site http://www.ntis.gov/support/ordernowabout.htm

Reports are available to DOE employees, DOE contractors, Energy Technology Data Exchange (ETDE) representatives, and International Nuclear Information System (INIS) representatives from the following source.

Office of Scientific and Technical Information

P.O. Box 62

Oak Ridge, TN 37831

Telephone 865-576-8401

Fax 865-576-5728

E-mail reports@osti.gov

Web site http://www.osti.gov/contact.html

This report was prepared as an account of work sponsored by an agency of the United States Government. Neither the United States Government nor any agency thereof, nor any of their employees, makes any warranty, express or implied, or assumes any legal liability or responsibility for the accuracy, completeness, or usefulness of any information, apparatus, product, or process disclosed, or represents that its use would not infringe privately owned rights. Reference herein to any specific commercial product, process, or service by trade name, trademark, manufacturer, or otherwise, does not necessarily constitute or imply its endorsement, recommendation, or favoring by the United States Government or any agency thereof. The views and opinions of authors expressed herein do not necessarily state or reflect those of the United States Government or any agency thereof. 


\title{
ADVANCING RESIDENTIAL RETROFITS IN THE MIXED-HUMID CLIMATE TO ACHIEVE DEEP ENERGY SAVINGS: FINAL REPORT ON KNOXVILLE, TN HOMES
}

\author{
Philip Boudreaux \\ Kaushik Biswas \\ Roderick Jackson
}

January 2013

\author{
Prepared by \\ OAK RIDGE NATIONAL LABORATORY \\ Oak Ridge, Tennessee 37831-6283 \\ managed by \\ UT-BATTELLE, LLC \\ for the \\ U.S. DEPARTMENT OF ENERGY \\ under contract DE-AC05-00OR22725
}





\section{TABLE OF CONTENTS}

\section{Page}

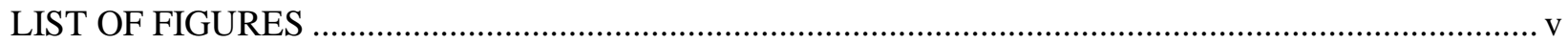

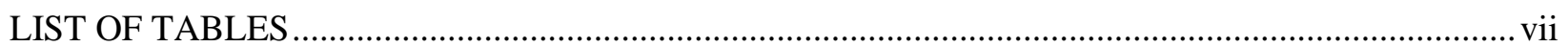

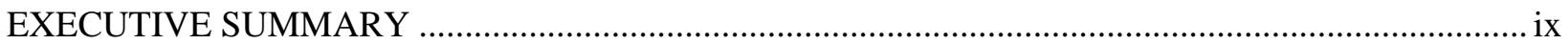

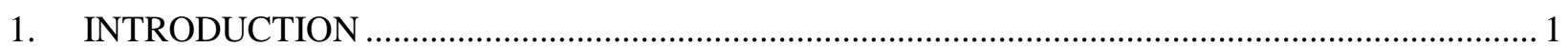

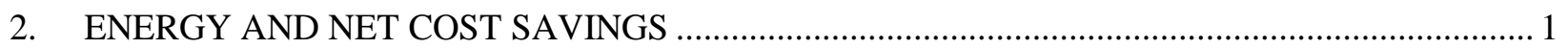

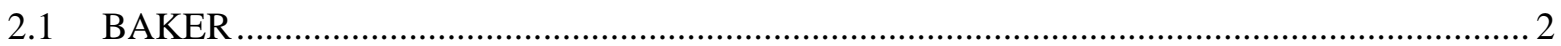

2.2 COUNTRY

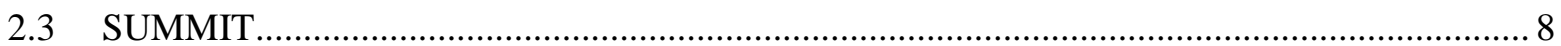

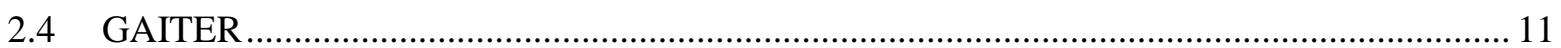

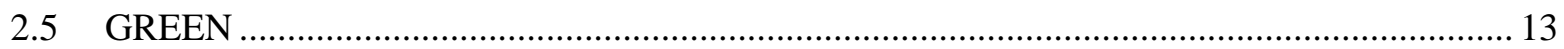

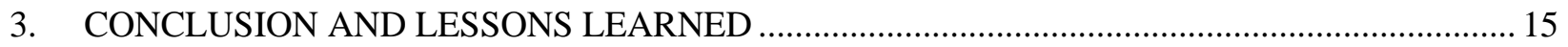

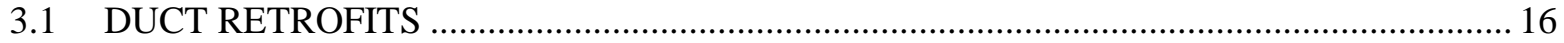

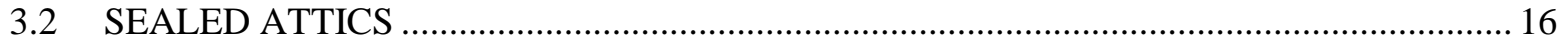

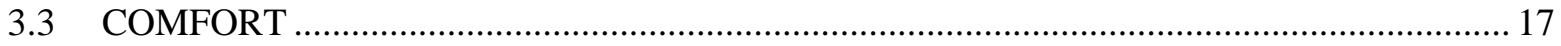

3.4 ENERGY RETROFITS DURING REMODELING OR REPAIRS …............................... 18

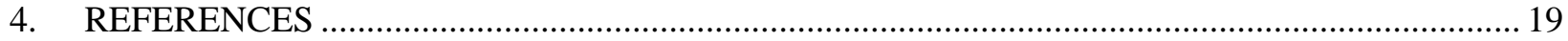

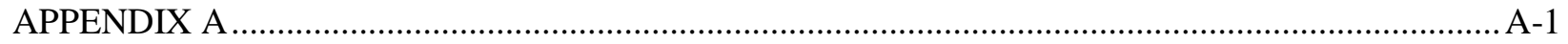

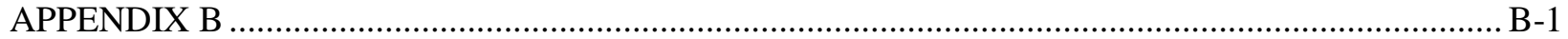





\section{LIST OF FIGURES}

Figures $\quad$ Page

Fig. ES-1. Site energy normalized by floor area for all homes......................................................... $\mathrm{x}$

Fig. 1. Pre- and post-retrofit Baker utility bills (electric and gas) plotted against outdoor air temperature with regressions.............................................................................................. 3

Fig. 2. Pre- and post-retrofit Country electric bills plotted against outdoor air temperature with

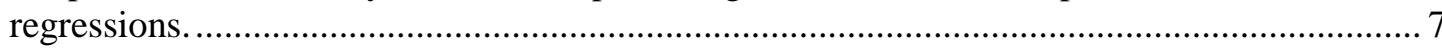

Fig. 3. Pre- and post-retrofit Summit utility bills (electric and gas) plotted against outdoor air temperature with regressions............................................................................................. 9

Fig. 4. Post-retrofit monthly energy use of Summit compared with weather corrected pre-retrofit energy use.

Fig. 5. Gaiter yearly total and subsystem energy of weather-corrected (to TMY3) measured data, calibrated post-retrofit model, and pre-retrofit model.....

Fig. 6. Green yearly total and subsystem energy of weather-corrected (to TMY3) measured data, calibrated post-retrofit model, and pre-retrofit model. .

Fig. 7. Site energy normalized by floor area for all homes.

Fig. 8. Heat flux from attic to living space of sealed and vented attics. 17 



\section{LIST OF TABLES}

\section{Tables}

Page

Table ES-1. Retrofit measures completed in each home ..... ix

Table ES-2. Measured energy savings at Baker, Country and Summit. Modeled energy savings at Gaiter and Green ix

Table ES-3. Cost-effectiveness of each retrofit package ................................................................

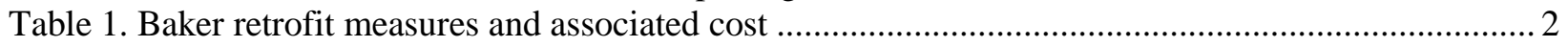

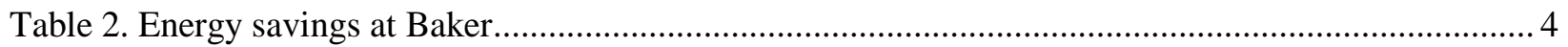

Table 3. Cost-effectiveness of the Baker retrofit package .................................................................... 4

Table 4. Water heater retrofit analysis for two cool months ................................................................... 4

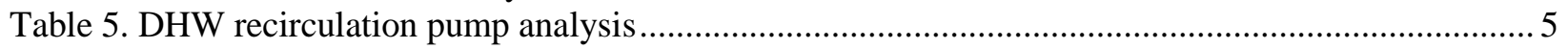

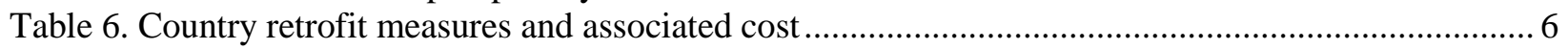

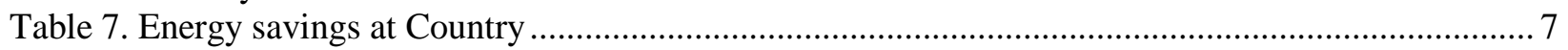

Table 8. Cost-effectiveness of retrofit package at Country .................................................................. 7

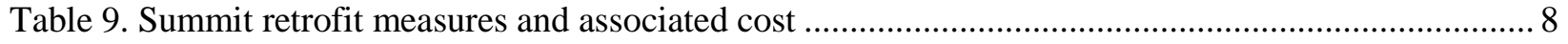

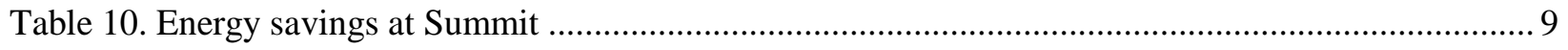

Table 11. Cost-effectiveness of retrofit package at Summit ............................................................. 9

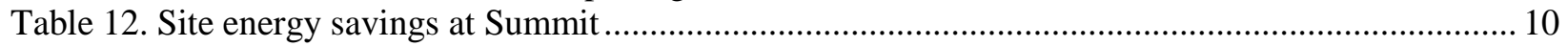

Table 13. Gaiter retrofit measures and associated cost. The grayed cells indicate estimated existing

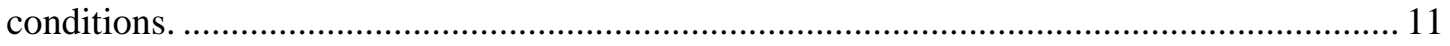

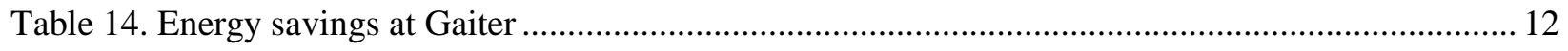

Table 15. Cost-effectiveness of retrofit package at Gaiter................................................................... 12

Table 16. Green retrofit measures and associated cost. The grayed cells indicate estimated existing

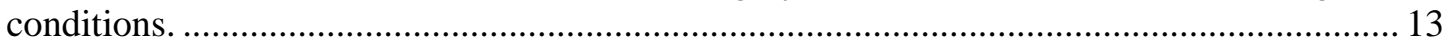

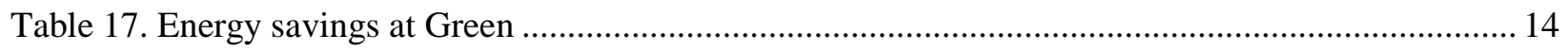

Table 18. Cost-effectiveness of retrofit package at Green ...................................................................... 14

Table 19. Measured energy savings at Baker, Country and Summit. Modeled energy savings at

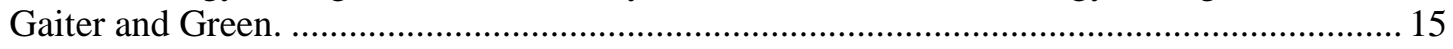

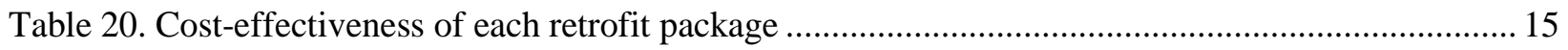




\section{ACKNOWLEDGEMENTS}

The authors would like to thank all of the homeowners who participated in this study. Their patience with sensor and data logger installation and hospitality as ORNL staff frequently visited their homes was greatly appreciated. Jeffrey Christian is acknowledged for obtaining funding for and beginning this project in 2010. Assistance provided by Anthony Gehl regarding insight into data acquisition and occupant behavior at the homes and Jeffrey Munk regarding HVAC operation were invaluable. The authors also thank Piljae Im and William Craddick for completing technical reviews of this report. 


\section{EXECUTIVE SUMMARY}

To contribute to the Department of Energy goal of enabling cost effective energy retrofits with 50\% source energy reduction of the residential house stock by 2030, Oak Ridge National Laboratory has spurred and analyzed residential retrofits in the mixed-humid climate around Knoxville, Tennessee. An in-depth description of all the homes in the study can be found in an interim report (Boudreaux et al. 2012) which includes descriptions of the implemented retrofits and their estimated energy savings and cost-effectiveness based on pre- and post-retrofit energy models. The aliases for the five homes are Baker, Country, Summit, Gaiter, and Green. Table ES-1 gives a qualitative view of the retrofit measures implemented at each home.

Table ES-1. Retrofit measures completed in each home

\begin{tabular}{|c|c|c|c|c|c|c|c|c|}
\hline & $\begin{array}{c}\text { Sealed } \\
\text { attic }\end{array}$ & $\begin{array}{c}\text { Attic } \\
\text { floor } \\
\text { sealing }\end{array}$ & $\begin{array}{l}\text { Attic floor } \\
\text { insulation }\end{array}$ & $\begin{array}{c}\text { Wall } \\
\text { insulation }\end{array}$ & $\begin{array}{l}\text { Window } \\
\text { upgrade }\end{array}$ & $\begin{array}{c}\text { HVAC } \\
\text { upgrade }\end{array}$ & $\begin{array}{c}\text { Subfloor/ } \\
\text { crawlspace } \\
\text { sealing }\end{array}$ & $\begin{array}{c}\text { DHW } \\
\text { upgrade }\end{array}$ \\
\hline Baker & & & $\mathrm{x}$ & & & $\mathrm{x}$ & $\mathrm{x}$ & $\mathrm{x}$ \\
\hline Country & & $\mathrm{x}$ & $\mathrm{x}$ & $\mathrm{x}$ & $\mathrm{x}$ & $\mathrm{x}$ & $\mathrm{x}$ & $\mathrm{x}$ \\
\hline Summit & & $\mathrm{x}$ & $\mathrm{X}$ & $\mathrm{x}$ & $\mathrm{x}$ & $\mathrm{x}$ & $\mathrm{x}$ & \\
\hline Gaiter & $\mathrm{x}$ & & & $\mathrm{x}$ & $\mathrm{x}$ & $\mathrm{x}$ & & $\mathrm{x}$ \\
\hline Green & $\mathrm{x}$ & & & $\mathrm{x}$ & $\mathrm{x}$ & $\mathrm{x}$ & $\mathrm{x}$ & $\mathrm{x}$ \\
\hline
\end{tabular}

In all the homes, the attic insulation was increased (either on the attic floor or the attic roof deck) and the heating, ventilation, and air-conditioning (HVAC) unit was upgraded to a more efficient unit. All of the homeowners took steps to decrease air infiltration. Most of the homeowners upgraded windows and domestic hot water (DHW) systems and completed some type of foundation sealing. Table ES-2 shows the energy savings at each home due to the retrofit package.

Table ES-2. Measured energy savings at Baker, Country and Summit. Modeled energy savings at Gaiter and Green

\begin{tabular}{c|c|c|c|c}
\multicolumn{2}{c}{ Electric (kWh) } & Gas (therms) & Site (MMBtu) & \multicolumn{1}{c}{ Source (MMBtu) } \\
\hline \hline Baker savings & $-21 \%$ & $61 \%$ & $32 \%$ & $8 \%$ \\
\hline Country savings & $33 \%$ & - & $33 \%$ & $33 \%$ \\
\hline Summit savings & $-19 \%$ & $86 \%$ & $61 \%$ & $33 \%$ \\
\hline Gaiter savings & $7 \%$ & $100 \%$ & $88 \%$ & $70 \%$ \\
\hline Green savings & $15 \%$ & $100 \%$ & $80 \%$ & $58 \%$
\end{tabular}

The percent source energy savings range from 8 to $70 \%$. This wide range of savings correlates well to the total cost of the retrofit package. Table ES-3 shows the cost-effectiveness of each retrofit package. The energy bill savings is the yearly savings between the post-retrofit and pre-retrofit condition, using values of $\$ 1 /$ therm and $\$ 0.10 / \mathrm{kWh}$. The net annual cost is the yearly loan payment (15 year, $7 \%$ interest) on the 
total retrofit cost minus the energy bill savings. The simple payback is the retrofit cost divided by the energy bill savings. If the retrofit were cost-effective, the net annual cost would be negative; notice that none of these retrofits were cost-effective. The simple payback time should be less than the equipment lifetime ( 15 years) and less than the homeowner plans to stay in the home.

Table ES-3. Cost-effectiveness of each retrofit package

Cost of retrofit

(\$)

Energy bill savings (\$) Net annual cost $(\$)$

Simple payback (year)

\begin{tabular}{c|c|c|c|c}
\hline \hline Baker & 14,929 & 230 & 1,380 & 65 \\
\hline Country & 23,835 & 648 & 1,922 & 37 \\
\hline Summit & 52,698 & 770 & 4,914 & 68 \\
\hline Gaiter & 36,699 & 1,700 & 2,582 & 23 \\
\hline Green & 35,230 & 1,458 & 2,342 & 24
\end{tabular}

Figure ES-1 shows the site energy of each home normalized by the floor area compared to the national and southern average. Notice that Green and Gaiter are significantly higher than the other three homes and the national and southern averages. Both are historic homes with high infiltration and little or no insulation. Although this study only involves 5 homes, it indicates that homes can be retrofit resulting in post-retrofit energy consumption at less than half of the national average even when their pre-retrofit energy usage might have been 2 to 3 times that of the national average.

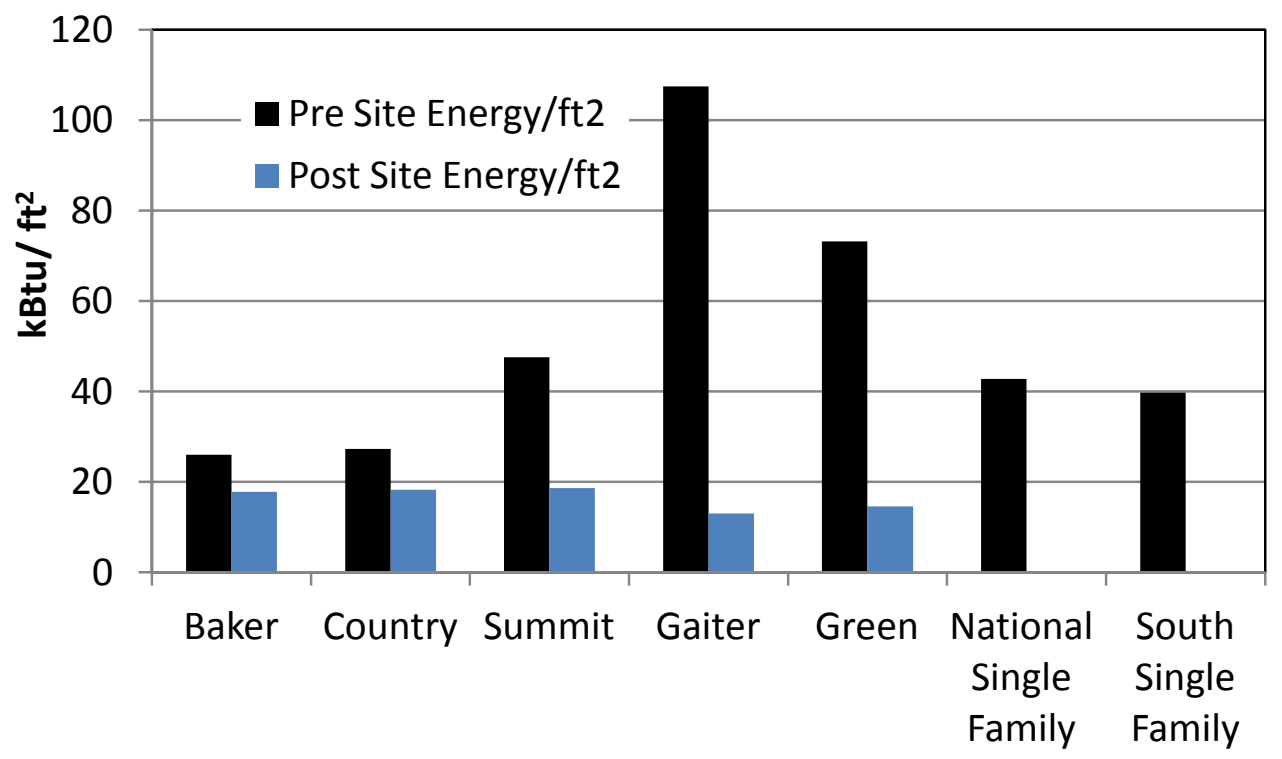

Fig. ES-1. Site energy normalized by floor area for all homes.

Most of the homeowners completed these retrofits in conjunction with extensive remodeling or home repairs. It is important that the building retrofit industry understand this point and capture the opportunity to implement energy-saving technologies and materials. Desire for a more comfortable home was found to be a recurring motivation for energy retrofits. This finding was determined from the homeowner interviews as well as from homeowner decisions involving equipment choices. Although homeowners 
would like to see energy bill savings, they were considered a secondary benefit of retrofits and not the main driver.

Other findings include an analysis of HVAC duct sealing/replacement in Baker and other retrofit homes. The average payback of these retrofits is 22 years, with highly variable retrofit costs normalized by conditioned floor area, from $\$ 0.92$ to $\$ 1.80 / \mathrm{ft}^{2}$. 


\section{INTRODUCTION}

To contribute to the Department of Energy (DOE) goal of enabling cost effective energy retrofits with $50 \%$ source energy reduction of the residential house stock by 2030, Oak Ridge National Laboratory (ORNL) has spurred and analyzed residential retrofits in the mixed-humid climate around Knoxville, Tennessee. An in-depth description of all the homes in the study can be found in an interim report (Boudreaux et al. 2012). The aliases for the five homes are Baker, Country, Summit, Gaiter, and Green. ORNL provided recommendations and collected metered data (e.g., submetered energy, temperature, humidity) at all five homes after the retrofits were complete. The homeowners paid for the retrofits and ultimately decided whether to take ORNL's advice. A year of post-retrofit utility bills has been collected, and from these bills, energy savings have been calculated.

In all the homes, the attic insulation was increased (either on the attic floor or the attic roof deck) and the heating, ventilation, and air-conditioning (HVAC) unit was upgraded to a more efficient unit. All of the homeowners took steps to decrease air infiltration. Most of the homeowners upgraded windows and domestic hot water (DHW) systems and completed some type of foundation sealing.

The following report will describe the energy savings and net cost savings (annualized retrofit cost less annual energy savings) of each home. Lessons learned based on the retrofit work and homeowner interviews will also be presented.

\section{ENERGY AND NET COST SAVINGS}

Energy savings due to retrofits were calculated for all homes. In cases where 12 months of pre- and postretrofit bills were available, Option $C^{1}$ in the IPMVP (International Performance Measurement and Verification Protocol) was used (IPMVP 2012). In the two homes that were unoccupied before the retrofit (Gaiter and Green), Option $D^{2}$ in the IPMVP was used. Net cost savings were also calculated for all homes. First the yearly energy bill cost savings was calculated from the energy savings. Equation (1) describes the yearly energy bill savings $(\Delta S)$, where $\Delta E$ is the electric energy savings and $\Delta G$ is the gas energy savings. The net cost savings is reported by Net Annual Cost, which is the yearly loan payment on the retrofit costs minus the yearly energy bill savings. The loan payment is calculated for a 15 year loan at $7 \%$ interest. Equation (2) describes the calculation for net annual cost, where $R$ is the retrofit cost. If net annual cost is positive, then the retrofit is not cost-effective. Simple payback is also reported, which is the retrofit cost divided by the yearly energy bill savings.

$$
\begin{gathered}
\Delta S[\$]=\Delta E \times \$ 0.10+\Delta G \times \$ 1.00 \\
\text { Net Annual Cost }[\$]=\left(R \times\left(0.07 / 12 /\left(1-(1+0.07 / 12)^{-180}\right)\right) \times 12\right)-\Delta S
\end{gathered}
$$

\footnotetext{
${ }^{1}$ The procedure for calculating energy savings in Option C involves using a year of pre- and post-retrofit energy bills. The energy bills are plotted against average outside air temperature for each billing period, and then a piecewise linear regression is applied to the energy-to-temperature relationship. This is done for each fuel type of the pre- and post-retrofit periods. TMY3 monthly temperature data are then used as the independent variable of each regression. After the yearly energy consumption of the pre- and post-retrofit cases are computed, energy savings can be determined.

${ }^{2}$ Option D involves calibrating a model of the post-retrofit home against the post-retrofit measured energy data. Once the model is calibrated, the model parameters describing the envelope and equipment are changed to estimated pre-retrofit. conditions. The yearly energy outputs of the two models are compared to determine the energy savings of the retrofits.
} 


\subsection{BAKER}

The Baker home is a 5,210 $\mathrm{ft}^{2}$ home built in 1966. Table 1 describes the retrofit measures completed at Baker and the associated costs. The air infiltration was reduced by $34 \%$ from 10.3 to $6.8 \mathrm{ACH}_{50}$. Although the pre-retrofit duct leakage was too great to measure, the post-retrofit duct leakage to the outside was $2.8 \%$ relative to the conditioned floor area. (See the interim report for more information on the home [Boudreaux et al. 2012]). Retrofits were completed in October 2010 (except the heat pump water heater, which was installed in January 2012).

Table 1. Baker retrofit measures and associated cost

\begin{tabular}{|c|c|c|c|}
\hline & Pre-retrofit & Post-retrofit & Cost (\$) \\
\hline Foundation & No band joist insulation & $\begin{array}{c}\text { Band joist: } \mathrm{R}-19 \\
\text { Air-sealed basement ceiling }\end{array}$ & 730 \\
\hline Walls & No band joist insulation & First floor band joist: R-9 & 727 \\
\hline Windows & & Air-sealed with caulk & 125 \\
\hline Doors & & $\begin{array}{l}\text { Weather-stripped and sealed doors; } \\
\text { replaced garage and basement } \\
\text { doors with metal units }\end{array}$ & 939 \\
\hline Attic/kneewalls & $\begin{array}{l}\text { Attic floor: R-30 } \\
\text { Attic kneewall: R-9 }\end{array}$ & $\begin{array}{c}\text { Attic floor: R-38 } \\
\text { Attic kneewall: R-19 } \\
\text { First floor flat attic: R-30 }\end{array}$ & 1,385 \\
\hline Cooling & 4 ton 10 SEER & 4 ton 16 SEER heat pump & \multirow[b]{2}{*}{9,523} \\
\hline Heating & $\begin{array}{l}\text { 6.8 HSPF with } \\
\text { hydronic backup }\end{array}$ & $\begin{array}{c}\text { 9.5 HSPF (90 kBtuh, 95\% AFUE } \\
\text { gas backup) }\end{array}$ & \\
\hline DHW & $\begin{array}{c}0.51 \text { EF natural gas water } \\
\text { heater }\end{array}$ & $\begin{array}{l}2.4 \mathrm{EF} \text { electric heat pump } \\
\text { water heater }\end{array}$ & 1,500 \\
\hline
\end{tabular}

Since the homeowner installed the heat pump water heater late into the post-retrofit period, a whole year of energy bills with the heat pump water heater installed was not available. However, a year of post-retrofit bills before the heat pump water heater installation was available, and these bills are presented below. The heat pump water heater retrofit will be considered in the final energy savings analysis in Table 2. The markers in Figure 1 show the pre- and post-retrofit energy consumption per day versus average outdoor air temperature (OAT) for each billing period. The solid lines show the piecewise linear regressions of energy versus temperature. The regressions were calculated using the American Society of Heating, Refrigerating and Air-Conditioning Engineers (ASHRAE) inverse modeling toolkit (Kissock, Haberl, and Claridge 2003). Appendix A shows the regression equations and statistics of each fit.

The following discussion focuses on Figure 1(a). Both the pre- and post-retrofit electricity consumptions were fit with five-parameter change point regressions because an electric heat pump heated and cooled the home in both cases. A five-parameter change point regression has a negative left hand slope, reflecting the increase in heating energy as the OAT decreases. The positive right hand slope reflects the increase in cooling energy as the OAT increases. Between these two slopes is a flat horizontal line, or baseline energy of the home. At these temperatures, the home needs minimal space conditioning. The transition between the heating slope and baseline and the baseline and cooling slope are called change points. The decreased left and right hand slope of the post-retrofit regression over the pre-retrofit regression reflect the increased efficiency of the new space-conditioning equipment and envelope. Notice that the electric base load increased after the retrofit. The heating and cooling contractor had told the 
homeowner to keep the heat pump blower on constantly during the summer to mix the air in the home to counteract poor duct design ${ }^{3}$. The difference in daily fan energy when the thermostat is set to "Fan On" versus "Fan Auto" is about $14 \mathrm{kWh}$. This explains the increase in the electric baseline seen after the retrofit in Figure 1(a).

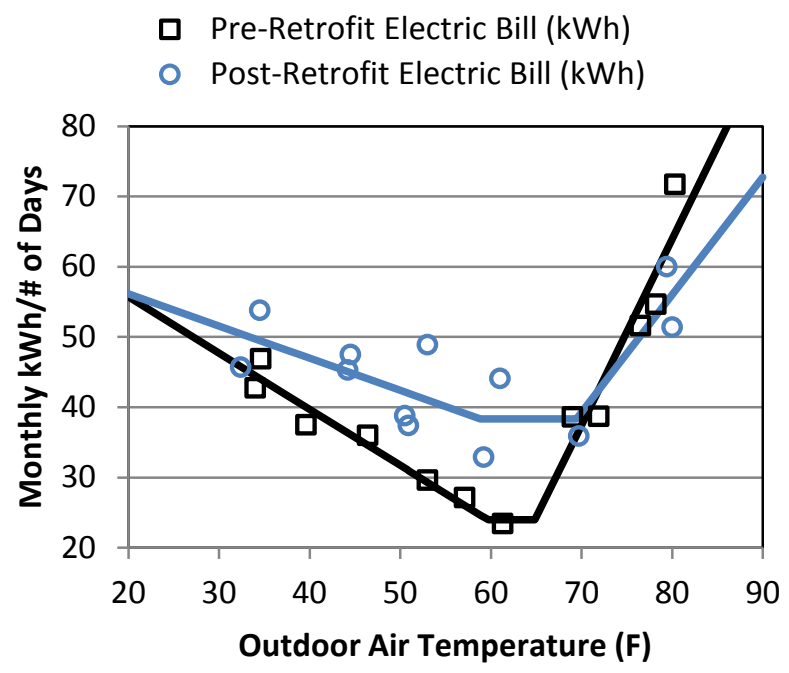

(a)

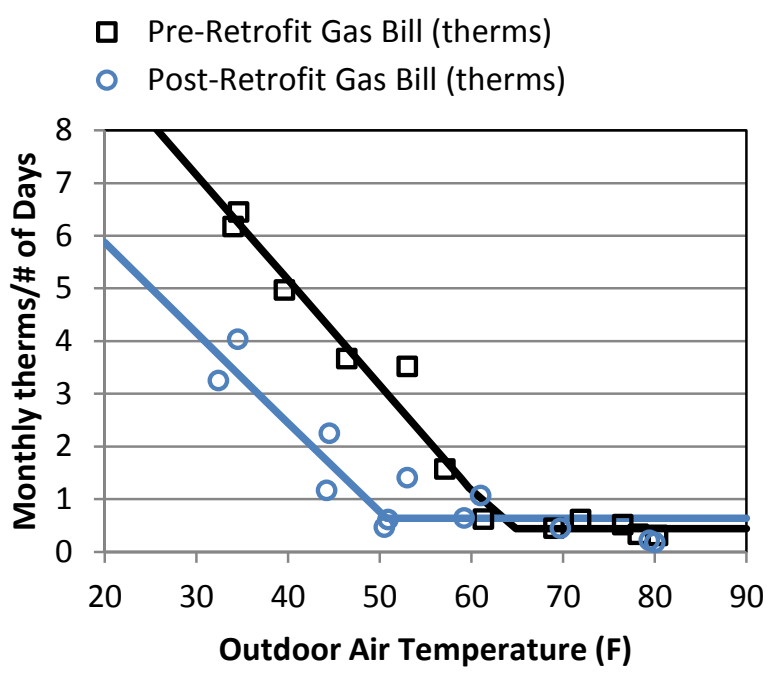

(b)

Fig. 1. Pre- and post-retrofit Baker utility bills (electric and gas) plotted against outdoor air temperature with regressions.

Figure 1(b) shows the gas consumption and regressions for the pre- and post-retrofit cases at Baker. Three-parameter heating change point regressions were used. This type of regression reflects the increased gas energy used to aid in space heating as the temperature decreases. On the right side of the change point is a baseline period, shown by the horizontal line, which reflects the gas water heater consumption in warmer months. The left slope in the colder months is due to the hydronic heat pump backup for the pre-retrofit case and the gas furnace heat pump backup for the post-retrofit case. This retrofit decreased the temperature change point of the gas consumption regression. This might indicate that the new heat pump doesn't need to call for auxiliary heat as soon as the pre-retrofit unit did as the temperatures fall and might be due to a different thermostat set-up before and after the retrofit. The tighter envelope could also have affected the decrease in the change point. The parallel left hand slope of both pre- and post-retrofit conditions might indicate that the efficiencies of the pre-retrofit hydronic and post-retrofit gas furnace backup are similar.

Using TMY3 monthly average OAT as the independent variable of the energy versus temperature regressions described above results in weather-corrected energy consumption for both cases. This procedure is described as Option C in the IPMVP (IPMVP 2012). The impact of the heat pump water heater retrofit was calculated by subtracting the estimated gas water heater energy from the TMY3-based gas consumption, and adding the estimated heat pump water heater energy to the TMY3-based electricity consumption. To do this monthly submetered energy consumption data for both water heaters were regressed against OAT. Then TMY3 monthly temperatures were used as the independent variable of the regressions. The final results are shown in Table 2 with 12 month tabulations of pre-retrofit, post-retrofit, site, and source energy consumption and associated percent savings.

\footnotetext{
${ }^{3}$ ORNL did not know the fan was set to "On" instead of "Auto" until the end of the post-retrofit period.
} 
Table 2. Energy savings at Baker

\begin{tabular}{l|c|c|c|c} 
& \multicolumn{1}{c}{ Electric $(\mathbf{k W h})$} & Gas (therms) & Site (MMBtu) & Source $^{4}(\mathbf{M M B})$ \\
\hline \hline Pre-retrofit & 14,282 & 867 & 135.4 & 253.5 \\
\hline Post-retrofit & 17,276 & 337 & 92.6 & 232.2 \\
\hline Percent savings & $-21 \%$ & $61 \%$ & $32 \%$ & $8 \%$
\end{tabular}

The Baker household saved 32\% in site energy and $8 \%$ in source energy. Table 3 shows the cost savings. In comparison to the other homes, Baker did the least amount of retrofits, which accounts for the lower retrofit cost. Despite $\$ 230$ of energy bill savings a year due to the retrofits, the loan payments are more than the bill savings. This means the homeowner has to pay an additional $\$ 1,380$ per year for 15 years, so this retrofit was not cost-effective.

Table 3. Cost-effectiveness of the Baker retrofit package

\begin{tabular}{c|c|c|c} 
Cost of retrofit (\$) & Energy bill savings (\$) & Net annual cost (\$) & $\begin{array}{c}\text { Simple payback } \\
\text { (year) }\end{array}$ \\
\hline \hline 14,929 & 230 & 1,380 & 65
\end{tabular}

Because there was a delay in installing the heat pump water heater in Baker, metered data at 1 minute resolution was available for both the gas and heat pump water heater in the winter of 2011. The original water heater was an 80 gallon natural gas-fired unit with a rated Efficiency Factor (EF) of 0.51. This unit was replaced on January 7, 2012, with a 50 gallon heat pump water heater with a rated EF of 2.4. A period of 31 days, with similar average cold water inlet temperature, was analyzed for both systems. Table 4 shows the results of the analysis of both systems.

Table 4. Water heater retrofit analysis for two cool months

\begin{tabular}{|c|c|c|c|c|c|c|c|}
\hline & $\begin{array}{l}\text { Start date } \\
\text { of analysis }\end{array}$ & $\begin{array}{c}\begin{array}{c}\text { Number of } \\
\text { days } \\
\text { analyzed }\end{array} \\
\end{array}$ & $\begin{array}{c}\text { Average inlet } \\
\text { water } \\
\text { temperature } \\
\text { over period } \\
\end{array}$ & $\begin{array}{c}\text { Total } \\
\text { energy } \\
\text { delivered by } \\
\text { DHW } \\
\end{array}$ & $\begin{array}{c}\begin{array}{c}\text { Total site } \\
\text { energy } \\
\text { consumption } \\
\text { of DHW }\end{array} \\
\end{array}$ & $\begin{array}{l}\text { Coefficient of } \\
\text { performance }\end{array}$ & $\begin{array}{c}\text { Total source } \\
\text { energy } \\
\text { consumption } \\
\text { of DHW } \\
\end{array}$ \\
\hline $\begin{array}{c}\text { Gas water } \\
\text { heater }\end{array}$ & $12 / 1 / 2011$ & $\begin{array}{c}31 \text { (1112 gal } \\
\text { usage) }\end{array}$ & $56^{\circ} \mathrm{F}$ & $467.5 \mathrm{kBtu}$ & $1172 \mathrm{kBtu}$ & 0.4 & $1227 \mathrm{kBtu}$ \\
\hline $\begin{array}{c}\text { Electric } \\
\text { heat } \\
\text { pump } \\
\text { water } \\
\text { heater }\end{array}$ & $3 / 1 / 2012$ & $\begin{array}{c}31 \text { (1007 gal } \\
\text { usage) }\end{array}$ & $58^{\circ} \mathrm{F}$ & $493.1 \mathrm{kBtu}$ & $276 \mathrm{kBtu}$ & 1.8 & $922 \mathrm{kBtu}$ \\
\hline
\end{tabular}

The calculated coefficients of performance for each system are comparable to the manufacturer's rating, considering that only winter performance was analyzed. Based on this analysis, the heat pump water heater saved $25 \%$ in source energy over the gas water heater during these cool months.

\footnotetext{
${ }^{4}$ Source energy was computed by multiplying the electric consumption (kBtu) by 3.34 and the gas consumption (kBtu) by 1.047 (from EPA document: ENERGY STAR Performance Ratings Methodology for Incorporating Source Energy Use).
} 
During the pre-retrofit energy audit at Baker, it was noticed that the DHW system had a recirculation pump to decrease the time it takes hot water to get to the tap. The Baker homeowner was advised to shut off the recirculation pump. After metering was installed, it was decided to conduct a short experiment to determine the DHW energy use with and without the recirculation pump. Table 5 shows the results of the experiment, in which for one week the pump was turned on. This week was compared with a similar week in terms of hot water inlet temperature and hot water consumption without the recirculation pump on. During this study the pre-retrofit gas water heater was installed. It was found that the energy consumption of the DHW system with the recirculation pump was over twice that of the system without the pump.

Table 5. DHW recirculation pump analysis

\begin{tabular}{|c|c|c|c|c|c|}
\hline & $\begin{array}{l}\text { Start date of } \\
\text { analysis }\end{array}$ & $\begin{array}{c}\text { Number of } \\
\text { days } \\
\text { analyzed }\end{array}$ & $\begin{array}{l}\text { Average inlet } \\
\text { water } \\
\text { temperature } \\
\text { over period }\end{array}$ & $\begin{array}{c}\text { Total site } \\
\text { energy } \\
\text { consumption } \\
\text { of DHW }\end{array}$ & $\begin{array}{c}\text { Cost to } \\
\text { homeowner }\end{array}$ \\
\hline $\begin{array}{l}\text { With recirculation } \\
\text { pump }\end{array}$ & $8 / 17 / 2011$ & $\begin{array}{l}7 \text { ( } 227 \text { gal } \\
\text { usage) }\end{array}$ & $75.0^{\circ} \mathrm{F}$ & $492 \mathrm{kBtu}$ & $\begin{array}{l}\$ 4.79(\text { at } \\
\$ 1 / \text { therm })\end{array}$ \\
\hline $\begin{array}{l}\text { Without recirculation } \\
\text { pump }\end{array}$ & $8 / 27 / 2011$ & $\begin{array}{l}\text { 7(220 gal } \\
\text { usage })\end{array}$ & $74.9^{\circ} \mathrm{F}$ & $233 \mathrm{kBtu}$ & $\begin{array}{l}\$ 2.27 \text { (at } \\
\$ 1 / \text { therm) }\end{array}$ \\
\hline
\end{tabular}




\subsection{COUNTRY}

The Country home is an all-electric 2,448 $\mathrm{ft}^{2}$ home built in the 1970s. Table 6 describes retrofit measures completed at Country and the associated costs. Air infiltration was reduced by $42 \%$, from 8.6 to $5.0 \mathrm{ACH}_{50}$. The pre-retrofit duct leakage to the outside was $23 \%$ and the post-retrofit duct leakage is $6.7 \%$ relative to the conditioned floor area. (See the interim report for more information on the home Boudreaux et al. 2012). All retrofits were completed by April 2011.

Table 6. Country retrofit measures and associated cost

Pre-retrofit

Post-retrofit

Cost (\$)

\begin{tabular}{|c|c|c|c|}
\hline Foundation & $\begin{array}{l}\text { Finished conditioned } \\
\text { basement/vented } \\
\text { crawlspace }\end{array}$ & $\begin{array}{c}\text { Basement band joist: R-16 Crawlspace } \\
\text { band joist: R-22 }\end{array}$ & 852 \\
\hline Walls & $\begin{array}{c}\text { Cavity: R-13 } \\
\text { Insulated sheating:R-4 }\end{array}$ & $\begin{array}{l}\text { Kitchen walls cavity: R-16 } \\
\text { Other exterior wall cavity: R-14 } \\
\text { Exterior insulating sheathing: R-9.3 }\end{array}$ & 5,157 \\
\hline Windows & Metal frame, single-pane & $\begin{array}{l}\text { Vinyl frame, double-pane } \\
\text { (U-Factor 0.3; SHGC 0.2) }\end{array}$ & 4,160 \\
\hline Attic/kneewalls & $\begin{array}{c}\text { Attic floor: R-19 } \\
\text { Kneewall cavity: R-13 }\end{array}$ & $\begin{array}{c}\text { Attic floor: R-50 } \\
\text { Kneewall cavity: R-19 } \\
\text { Kneewall sheathing: R-13 } \\
\end{array}$ & 1,605 \\
\hline Cooling & $\begin{array}{l}2.5 \text { ton } 12 \text { SEER heat } \\
\text { pump } \\
\text { Package unit with } 5 \mathrm{~kW} \\
\text { electric backup }\end{array}$ & 3 ton 19 SEER heat pump & 8,705 \\
\hline Heating & $8 \mathrm{HSPF}$ & $9 \mathrm{HSPF}$ & \\
\hline DHW & $\begin{array}{l}0.91 \text { EF electric resistance } \\
\text { water heater }\end{array}$ & $\begin{array}{l}2.4 \mathrm{EF} \text { electric heat pump } \\
\text { water heater }\end{array}$ & 2,100 \\
\hline Lighting & $100 \%$ incandescent & $96 \% \mathrm{CFL}$ & 276 \\
\hline Appliances & $\begin{array}{l}\text { Non-ENERGY STAR® } \\
\text { appliances }\end{array}$ & ENERGY STAR $®$ refrigerator & 980 \\
\hline
\end{tabular}

The markers in Figure 2 show the pre- and post-retrofit electricity consumption per day versus average OAT for each billing period. The solid lines show the piecewise linear regressions of energy versus temperature. The same procedure used for calculating energy savings at Baker was used for Country. 


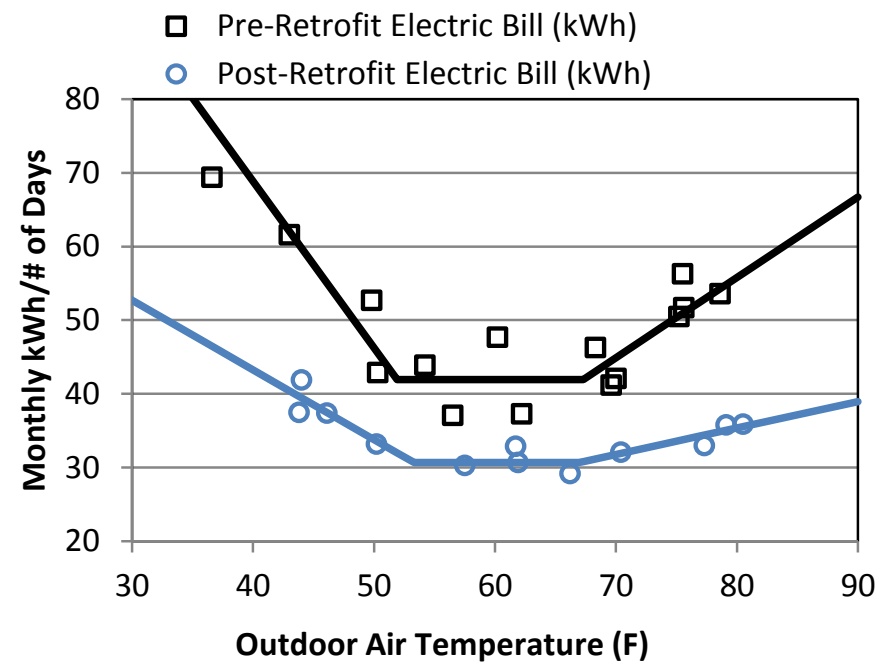

Fig. 2. Pre- and post-retrofit Country electric bills plotted against outdoor air temperature with regressions.

Appendix A shows the regression equations and statistics of each fit. The electric baseline was lowered by the retrofit, probably because of the appliance, lighting, and water heater retrofit. Notice also that the right and left hand slope have decreased in the post-retrofit condition. This is due to the decreased air infiltration, increased insulation (including windows), and HVAC retrofits (including ducts).

The energy versus temperature regressions shown in Figure 2 were used to calculate the energy savings of this retrofit in the same manner that the energy savings at Baker were calculated, and are shown in Table 7. The retrofit savings were $33 \%$ for both site and source energy. Table 8 shows the cost analysis of the Country retrofit. The homeowner spent $\$ 23,835$, and saved $\$ 648$ this past year. The retrofit was not costeffective, however, with a net annual cost of $\$ 1,922$.

Table 7. Energy savings at Country

Electric (kWh) Site (MMBtu) Source (MMBtu)

\begin{tabular}{c|c|c|c}
\hline \hline Pre-retrofit & 19,619 & 66.9 & 223.6 \\
\hline Post-retrofit & 13,135 & 44.8 & 149.7 \\
\hline Percent savings & $33 \%$ & $33 \%$ & $33 \%$
\end{tabular}

Table 8. Cost-effectiveness of retrofit package at Country

\begin{tabular}{c|c|c|c} 
Cost of retrofit (\$) & Energy bill savings (\$) & Net annual cost (\$) & $\begin{array}{c}\text { Simple payback } \\
\text { (year) }\end{array}$ \\
\hline \hline 23,835 & 648 & 1,922 & 37
\end{tabular}




\subsection{SUMMIT}

The Summit home is a 3,110 $\mathrm{ft}^{2}$ home built in the 1990s. Table 9 describes the retrofit measures completed at Summit and the associated costs. The air infiltration was reduced by 58\%, from 9.1 to 3.9 $\mathrm{ACH}_{50}$. A multi-split HVAC system was installed in Summit, so there is no post-retrofit duct leakage.

Table 9. Summit retrofit measures and associated cost

\begin{tabular}{|c|c|c|c|}
\hline & Pre-retrofit & Post-retrofit & $\operatorname{Cost}(\$)$ \\
\hline Foundation & Uninsulated basement walls & Above-grade exterior insulation & 10,691 \\
\hline Walls & $\mathrm{R}-13$ & $\begin{array}{l}\text { Added R-3 sheathing to } \\
\text { all exterior walls, improved } \\
\text { walls adjacent to garage to R-19 } \\
\text { (cavity) and R-10 (sheathing) }\end{array}$ & 5,178 \\
\hline Windows & Vinyl frame, double-pane & $\begin{array}{l}\text { Vinyl frame, triple- and quad- } \\
\text { pane (U-factor } 0.1 \text { and } 0.2 \text {; } \\
\text { SHGC, 0.35) }\end{array}$ & 16,363 \\
\hline Attic/kneewalls & $\begin{array}{l}\text { R-38 in attic, no insulation } \\
\text { on kneewall }\end{array}$ & $\begin{array}{l}\text { R-60 attic insulation, } \\
\text { R-10 on kneewall }\end{array}$ & 6,311 \\
\hline Cooling & 5 ton (3 ton/2 ton) $13 \mathrm{SEER}$ & $\begin{array}{c}\text { Two } 3 \text { ton multi-split heat } \\
\text { pumps } 15 \text { SEER }\end{array}$ & 12,739 \\
\hline Heating & $\begin{array}{c}64 \text { kBtuh gas furnace } 75 \% \\
\text { AFUE }\end{array}$ & 8.7 HSPF & \\
\hline Lighting & $5 \% \mathrm{CFL}$ & $100 \%$ high efficiency & 436 \\
\hline Refrigerator & non-ENERGY STAR® & ENERGY STAR® & 980 \\
\hline Solar PV system & None & $8.5 \mathrm{~kW}$ peak & 34,175 \\
\hline
\end{tabular}

(See the interim report for more information on the home [Boudreaux, Christian, and Jackson 2012]). All retrofits were completed by July 2011.

The markers in Figure 3 show the pre- and post-retrofit energy consumption per day versus average OAT for each billing period. The solid lines show the piecewise linear regressions of energy versus temperature. The plots do not take into account the photovoltaic (PV) production at Summit. The same procedure used for calculating energy savings at Baker and Country was used for Summit. Appendix A shows the regression equations and statistics of each fit.

Figure 3(a) shows the pre- and post-retrofit electricity consumption at Summit. The pre-retrofit energy versus temperature regression is a three-parameter cooling change point regression because the home was cooled by an electric air conditioner but had a gas furnace for heating. The post-retrofit case was fit using a five-parameter change point regression because the electric heat pumps installed during the retrofit condition the home in heating and cooling seasons. The electric base load has decreased and is most likely due to the high-efficiency lighting and appliance retrofits. The right hand slope has decreased because of the HVAC and envelope retrofits.

Figure 3(b) shows the pre- and post-retrofit gas usage of Summit. Because the only gas appliance after the retrofit is the water heater, there is little correlation between air temperature and gas usage in the postretrofit condition. Because of the fuel switch in the heating system discussed above, the cold weather gas usage decreased tremendously after the retrofit. 
ㅁ Pre-Retrofit Electric Bill (kWh)

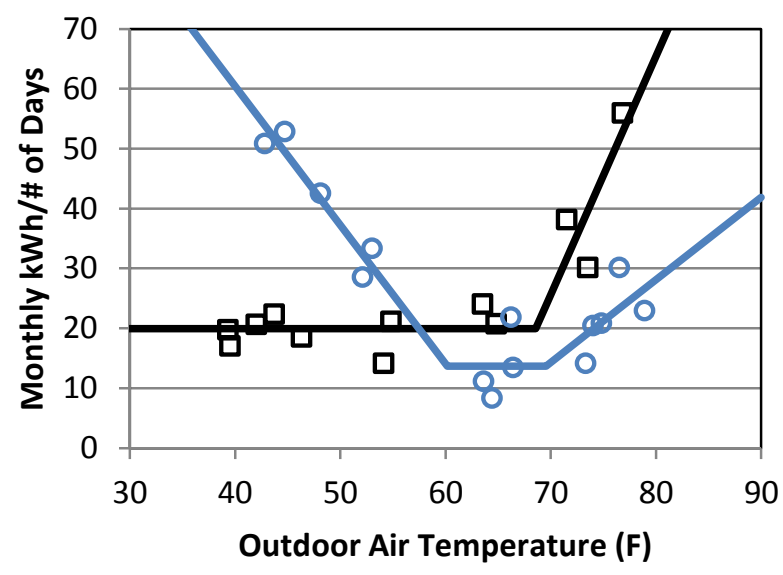

(a)
口 Pre-Retrofit Gas Bill (therms)

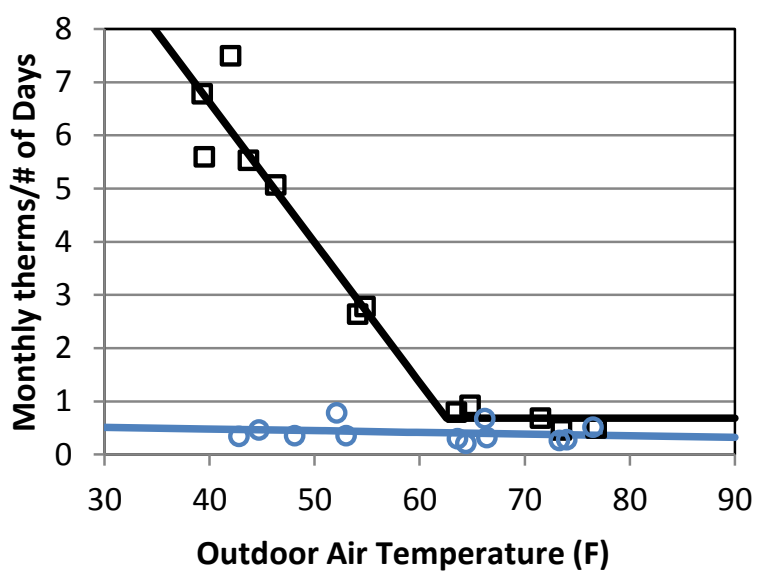

(b)

Fig. 3. Pre- and post-retrofit Summit utility bills (electric and gas) plotted against outdoor air temperature with regressions.

The regressions shown in Figure 3 were used to calculate the energy savings of this retrofit. Table 10 shows the results. The site energy savings was $61 \%$ and the source energy savings was $33 \%$. Notice the large decrease in gas consumption after the retrofit compared with the increase in electricity consumption; this difference is due to the switch from a gas furnace to an electric heat pump.

Table 10. Energy savings at Summit

\begin{tabular}{c|c|c|c|c} 
& Electric (kWh) & Gas (therms) & Site (MMBtu) & Source (MMBtu) \\
\hline \hline Pre-retrofit & 10,484 & 1,120 & 147.8 & 236.8 \\
\hline Post-retrofit & 12,444 & 155 & 58.0 & 158.0 \\
\hline Percent savings & $-19 \%$ & $86 \%$ & $61 \%$ & $33 \%$
\end{tabular}

Table 11 shows the cost analysis of the Summit retrofit. The homeowner spent \$52,698 (not counting PV), with an estimated $\$ 770$ in energy bill savings. The retrofit was not cost-effective - the net annual cost was $\$ 4,914$.

Table 11. Cost-effectiveness of retrofit package at Summit

\begin{tabular}{c|c|c|c} 
Cost of retrofit (\$) & Energy bill savings (\$) & Net annual cost (\$) & $\begin{array}{c}\text { Simple payback } \\
\text { (year) }\end{array}$ \\
\hline \hline 52,698 & 770 & 4,914 & 68
\end{tabular}

ORNL also analyzed the site energy consumption of the home considering the PV production. Figure 4 shows the site energy for the pre-retrofit condition, the post-retrofit condition without PV, and the postretrofit condition with PV. In this case the pre-retrofit condition is weather-corrected to post-retrofit weather instead of TMY3, and the post-retrofit energy is not weather-corrected. Notice that the monthly 
consumption is negative between April and October; during these months the PV generated more energy than the home consumed. Notice also that the biggest savings are seen in the winter.

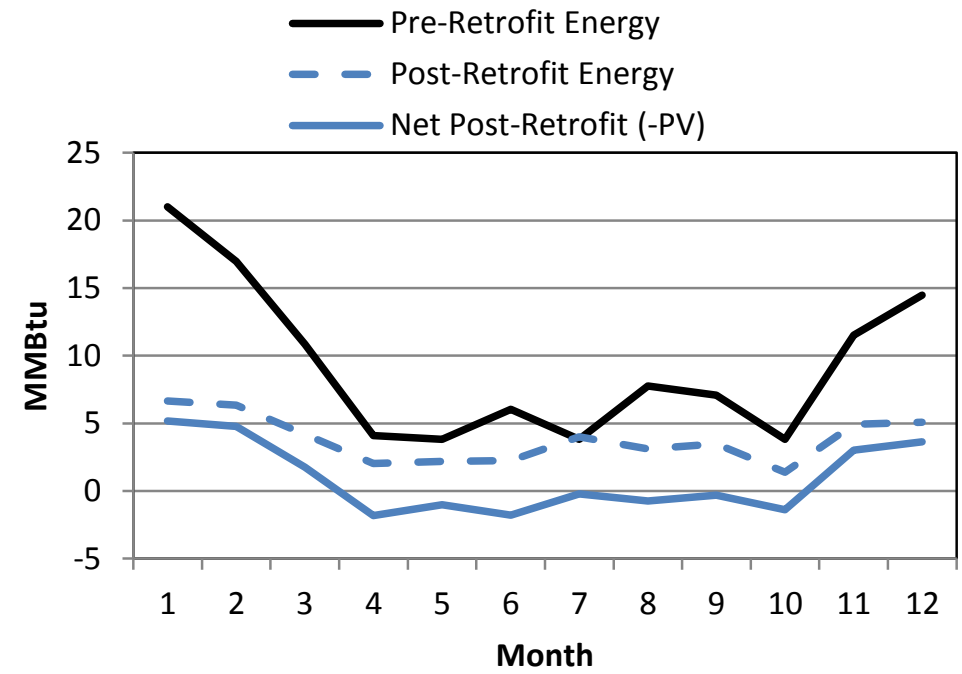

Fig. 4. Post-retrofit monthly energy use of Summit compared with weather corrected pre-retrofit energy use.

This is because the insulation and air-infiltration retrofits were most effective when the temperature difference between the indoor and outdoor environment was the largest, which is during the winter in the mixed-humid climate.

Table 12 shows the site energy and cost analysis with PV generation considered. With PV, the site energy savings was $90 \%$. The homeowner paid no energy bills during the post-retrofit period and in fact received over $\$ 1,000$ in credit from the utility provider. This savings was due in part to the TVA Generation Partner program, which pays a $\$ 0.12 / \mathrm{kWh}$ premium over the retail cost on energy produced by the homeowner. With PV, the cost of the retrofit was $\$ 86,873$, and the retrofit was still not cost-effective.

Table 12. Site energy savings at Summit

\begin{tabular}{c|c|c} 
& Site (MMBtu) & Energy Cost (\$) \\
\hline \hline Pre-retrofit & 111.2 & 1,735 \\
\hline Post-retrofit & 11.1 & $(1,058)$ \\
\hline Percent savings & $90 \%$ & $161 \%$
\end{tabular}




\subsection{GAITER}

The Gaiter home is a 1,769 $\mathrm{ft}^{2}$ home built in the 1940s. It was a gut-retrofit case that involved exposing all wall cavities so that they could be air-sealed with $1 \mathrm{in}$. of closed-cell foam and insulated with batts. Table 13 describes the retrofit measures completed at Gaiter with the associated costs. The air infiltration was reduced by $68 \%$, from 16.9 to $5.3 \mathrm{ACH}_{50}$, after the retrofit. Since this home was unoccupied before the retrofit, some of the equipment had already been removed from the home by the time the preliminary energy audit was done. This was the case with the duct work. The post-retrofit duct work was measured to have a leakage rate to the outside of $5 \%$ relative to the conditioned floor area. (See the interim report for more information on the home [Boudreaux et al. 2012]). The retrofit was completed in December 2011.

Table 13. Gaiter retrofit measures and associated cost. The grayed cells indicate estimated pre-retrofit conditions.

Pre-retrofit

Post-retrofit

Cost (\$)

\begin{tabular}{|c|c|c|c|}
\hline Attic & $\mathrm{R}-7$ on attic floor & Insulated roof deck to R-34 & 6,251 \\
\hline Cathedral ceiling in sunroom & None & $\mathrm{R}-24$ & 828 \\
\hline $\begin{array}{l}\text { Exterior walls (including } \\
\text { framed basement wall) }\end{array}$ & None & $\mathrm{R}-16$ & 2,665 \\
\hline Band-joist in basement & None & $\mathrm{R}-6$ & 280 \\
\hline Cooling & 3 ton, 10 SEER AC & 3 ton, 18 SEER heat pump & \multirow[t]{2}{*}{7,820} \\
\hline Heating & $\begin{array}{c}96 \mathrm{kBtuh} \text { gas furnace } 75 \% \\
\text { AFUE }\end{array}$ & 9.5 HSPF & \\
\hline DHW & $0.54 \mathrm{EF} 40$ gallon gas & 2.4 EF electric heat pump & 1,360 \\
\hline Windows & $\begin{array}{l}\text { Wood or vinyl frame, single } \\
\text { pane }\end{array}$ & $\begin{array}{l}\text { Wood frame, triple pane } \\
\text { U-factor } 0.2 ; \text { SHGC } 0.35\end{array}$ & 20,000 \\
\hline Appliances & Modeling software default & $\begin{array}{l}\text { ENERGY STAR® } \\
\text { refrigerator }\end{array}$ & 350 \\
\hline Lighting & $100 \%$ Incandescent & $90 \%$ CFL & 145 \\
\hline
\end{tabular}

HPSF $=$ heating season performance factor

Because Gaiter was unoccupied before the retrofit, no utility bills were available for energy savings calculations. Therefore, Option D in IPMVP was used to determine savings (IPMVP 2012). This procedure involves calibrating an energy model of the post-retrofit home against utility bills and metered data, and then changing the building characteristics in the model to those of the pre-retrofit condition of the home. These two yearly energy model outputs - calibrated, modeled post-retrofit energy use and modeled pre-retrofit energy use-are compared to determine energy savings. Figure 5 shows the results from the models. First, the daily post-retrofit energy consumption was regressed against OAT. TMY3 temperature data were used as the independent variable for the regression, resulting in yearly consumption of the post-retrofit home for TMY3 weather. These results are shown in column one of Figure 5. Column two is the calibrated (to column one) post-retrofit model output. The modeled monthly energy consumption was compared to the TMY3 normalized measured energy and a CV-RMSE of 22\% was found. The total yearly modeled energy consumption had a difference of $1 \%$ from the measured yearly energy total. Column three is the pre-retrofit model (which is based on the calibrated post-retrofit model) output. For more details on this procedure, see Appendix B.

Table 14 shows the energy savings based on the models. The site energy savings was $88 \%$ and the source energy savings was $70 \%$. Notice the large decrease in gas consumption compared with electricity 
consumption; this was due to the switch from a gas furnace and a gas water heater to a heat pump and a heat pump water heater, respectively.

\begin{tabular}{|c|c|c|c|c|c|c|}
\hline \multicolumn{2}{|c|}{$\begin{array}{l}\text { Post-retrofit Energy Usage } \\
\text { fit to TMY3 Data }\end{array}$} & \multicolumn{2}{|c|}{$\begin{array}{c}\text { EnergyGauge Post-retrofit } \\
\text { Output }\end{array}$} & \multicolumn{3}{|c|}{ EnergyGauge Pre-retrofit Output } \\
\hline End-Use & kWh & End-Use & kWh & End-Use & kWh & Therm \\
\hline & & Cooling & 745 & Cooling & 3533 & \\
\hline & & Heating & 3846 & Heating & 964 & 1526 \\
\hline Heating + Cooling & 4555 & Heating + Cooling & 4591 & Heating + Cooling & 4497 & 1526 \\
\hline Hot Water & 784 & Hot Water & 796 & Hot Water & & 120 \\
\hline Hot Water Pump & 0 & Hot Water Pump & 0 & Hot Water Pump & & \\
\hline Total Hot Water & 784 & Total Hot Water & 796 & Total Hot Water & & 120 \\
\hline Washer & 14 & Washer & 15 & Washer & 15 & \\
\hline Dishwasher & 22 & Dishwasher & 22 & Dishwasher & 22 & \\
\hline Dryer & 211 & Dryer & 211 & Dryer & 211 & \\
\hline Lighting & 586 & Lighting & 592 & Lighting & 2023 & \\
\hline Misc. & 0 & Misc. & 0 & Misc. & 0 & \\
\hline Range & 5 & Range & 5 & Range & 5 & \\
\hline Refrigerator & 541 & Refrigerator & 541 & Refrigerator & 541 & \\
\hline Total $^{1}$ & 6718 & Total & 6773 & Total & 7314 & $\overline{1646}$ \\
\hline \multirow[t]{3}{*}{ Whole House ${ }^{2}$} & 6700 & & & & & \\
\hline & & Total Site (MBtu) & 23.1 & Total Site (MBtu) & 190 & \\
\hline & & Total Source (MBtu) & 77.2 & Total Source (MBtu) & 256 & \\
\hline
\end{tabular}

${ }^{1}$ Sum of the individual end-uses

${ }^{2}$ Measured whole house usage

Fig. 5. Gaiter yearly total and subsystem energy of weather-corrected (to TMY3) measured data, calibrated post-retrofit model, and pre-retrofit model.

Table 14. Energy savings at Gaiter

\begin{tabular}{c|c|c|c|c}
\multicolumn{2}{c}{ Electric $(\mathbf{k W h})$} & Gas (therms) & Site (MMBtu) & Source (MMBtu) \\
\hline Pre-retrofit & 7,314 & 1646 & 190 & 256 \\
\hline Post-retrofit & 6,773 & 0 & 23.1 & 77.2 \\
\hline Percent savings & $7 \%$ & $100 \%$ & $88 \%$ & $70 \%$
\end{tabular}

Table 15 shows the cost-effectiveness of the retrofit. The homeowner spent $\$ 36,699$, and saved $\$ 1,700$ during the post-retrofit period. The retrofit was not cost-effective, with a net annual cost of $\$ 2,582$.

Table 15. Cost-effectiveness of retrofit package at Gaiter

\begin{tabular}{c|c|c|c} 
Cost of retrofit (\$) & Energy bill savings (\$) & Net annual cost (\$) & $\begin{array}{c}\text { Simple payback } \\
\text { (year) }\end{array}$ \\
\hline \hline 36,699 & 1,700 & 2,582 & 23
\end{tabular}




\subsection{GREEN}

The Green home is a 2,295 $\mathrm{ft}^{2}$ home built in 1909. This home was a gut-retrofit case that involved exposing all wall cavities so that insulation could be added. Table 16 describes the retrofit measures completed at Green with the associated costs. The pre-retrofit air infiltration was not measured but the post-retrofit infiltration is $5.5 \mathrm{ACH}_{50}$. Since this home was unoccupied before the retrofit some of the equipment was already removed from the home by the time the preliminary energy audit was done. This was the case with the duct work. The post-retrofit duct work was measured to have a leakage rate to the outside of $3.2 \%$ by conditioned floor area. (See the interim report for more information on the home [Boudreaux et al. 2012].) Retrofits were completed by May 2011.

Table 16. Green retrofit measures and associated cost. The grayed cells indicate estimated existing conditions.

\section{Pre-retrofit}

Post-retrofit

Cost $(\$)$

\begin{tabular}{|c|c|c|c|}
\hline Exterior Walls & R-5 & $\mathrm{R}-16$ & \multirow{3}{*}{13,506} \\
\hline Attic & None & $\begin{array}{l}\text { R-38 on underside of } \\
\text { roof deck }\end{array}$ & \\
\hline Basement Walls & None & $\begin{array}{c}\mathrm{R}-10 \text { foam panels on } \\
\text { basement walls with } \\
\text { vapor barrier }\end{array}$ & \\
\hline Cooling & 4 ton, 10 SEER AC & $\begin{array}{l}3 \text { ton, } 20.5 \text { SEER } \\
\text { variable capacity }\end{array}$ & \multirow{2}{*}{2,160} \\
\hline Heating & $\begin{array}{c}120 \mathrm{kBtuh} \text { gas furnace, } 75 \% \\
\text { AFUE }\end{array}$ & $13 \mathrm{HSPF}$ & \\
\hline DHW & 0.62 EF 50 gallon gas & Solar water heater & \multirow[b]{2}{*}{18,232} \\
\hline PV & None & $\begin{array}{l}1.428 \mathrm{~kW}_{\text {peak }} \\
\text { laminate PV }\end{array}$ & \\
\hline Windows & Wood frame, single pane & $\begin{array}{c}\text { Wood frame, double } \\
\text { pane } \\
\text { U-factor } 0.3 \text {; SHGC } \\
0.2\end{array}$ & 11,449 \\
\hline Lighting & $100 \%$ incandescent & $78 \%$ CFL & 115 \\
\hline
\end{tabular}

Because Green was unoccupied before the retrofit, no utility bills were available for energy savings calculations, so Option D in IPMVP was used to determine savings (IPMVP 2012). The procedure is the same as was used for Gaiter. Figure 6 presents the results from the models. First, the daily post-retrofit energy consumption was regressed against OAT. These data do not include the PV production. TMY3 data were used as the independent variable for the regression to provide the yearly energy consumption for the post-retrofit home. These results are shown in column one of Figure 6. Column two is the calibrated (to column one) post-retrofit model output. The modeled monthly energy consumption was compared to the TMY3 normalized measured energy and a CV-RMSE of $10 \%$ was found. The total yearly modeled energy consumption had a difference of $10 \%$ from the measured yearly energy total. Column three is the pre-retrofit model (that is based on the calibrated post-retrofit model) output. Appendix B presents more information on this procedure. 


\begin{tabular}{|c|c|c|c|c|c|c|}
\hline \multicolumn{2}{|c|}{$\begin{array}{c}\text { Post-retrofit Energy Usage } \\
\text { fit to TMY3 Data }\end{array}$} & \multicolumn{2}{|c|}{$\begin{array}{c}\text { EnergyGauge Post-retrofit } \\
\text { Output }\end{array}$} & \multicolumn{3}{|c|}{ EnergyGauge Pre-retrofit Output } \\
\hline End-Use & $\mathrm{kWh}$ & End-Use & $\mathrm{kWh}$ & End-Use & $\mathrm{kWh}$ & Therm \\
\hline & & Cooling & 983 & Cooling & 5616 & \\
\hline & & Heating & 3967 & Heating & 750 & 1174 \\
\hline Heating + Cooling & 4827 & Heating + Cooling & 4950 & Heating + Cooling & 6366 & 1174 \\
\hline Hot Water & 679 & Hot Water & 913 & Hot Water & & 117 \\
\hline Hot Water Pump & 501 & Hot Water Pump & 278 & Hot Water Pump & & \\
\hline Total Hot Water & 1180 & Total Hot Water & 1191 & Total Hot Water & & 117 \\
\hline Washer & 122 & Washer & 122 & Washer & 122 & \\
\hline Dishwasher & 36 & Dishwasher & 36 & Dishwasher & 36 & \\
\hline Dryer & 122 & Dryer & 122 & Dryer & 122 & \\
\hline Lighting & & Lighting & 1026 & Lighting & 2478 & \\
\hline Misc. & 2882 & Misc. & 1857 & Misc. & 1857 & \\
\hline Range & 63 & Range & 63 & Range & 63 & \\
\hline Refrigerator & 422 & Refrigerator & 422 & Refrigerator & 422 & \\
\hline Total $^{1}$ & 9653 & Total & 9789 & Total & 11466 & 1290 \\
\hline \multirow[t]{3}{*}{ Whole House ${ }^{2}$} & 10926 & & & & & \\
\hline & & Total Site (MBtu) & 33.4 & Total Site (MBtu) & 168 & \\
\hline & & Total Source (MBtu) & 112 & Total Source (MBtu) & 266 & \\
\hline
\end{tabular}

\footnotetext{
${ }^{1}$ Sum of the individual end-uses

${ }^{2}$ Measured whole house usage
}

Fig. 6. Green yearly total and subsystem energy of weather-corrected (to TMY3) measured data, calibrated post-retrofit model, and pre-retrofit model.

Presented in Table 17 are the energy savings based on the models. The site energy savings is $80 \%$ and the source energy savings is $58 \%$. Notice the large decrease in gas consumption over electricity consumption; this is due to switching from a gas furnace and a gas water heater to a heat pump and a solar thermal DHW system, respectively.

Table 17. Energy savings at Green

\begin{tabular}{c|c|c|c|c} 
& \multicolumn{1}{c}{ Electric $(\mathbf{k W h})$} & \multicolumn{1}{c}{ Gas (therms) } & Site (MMBtu) & Source (MMBtu) \\
\hline \hline Pre-retrofit & 11,466 & 1290 & 168 & 266 \\
\hline Post-retrofit & 9789 & 0 & 33.4 & 112 \\
\hline Percent savings & $15 \%$ & $100 \%$ & $80 \%$ & $58 \%$
\end{tabular}

Table 18 shows the cost-effectiveness of the retrofit. The homeowner spent $\$ 35,230$ (without PV) and saved $\$ 1,458$ during the post-retrofit period. The retrofit was not cost-effective, with a net annual cost of $\$ 2,342$. If $\mathrm{PV}$ is considered, then the energy savings was $83 \%$ and the retrofit cost was $\$ 45,462$. Even when PV is included, the retrofit was still not cost-effective.

Table 18. Cost-effectiveness of retrofit package at Green

\begin{tabular}{c|c|c|c} 
Cost of retrofit (\$) & Energy bill savings (\$) & Net annual cost (\$) & $\begin{array}{c}\text { Simple payback } \\
\text { (year) }\end{array}$ \\
\hline \hline 35,230 & 1,458 & 2,342 & 24
\end{tabular}




\section{CONCLUSION AND LESSONS LEARNED}

Five households in the mixed-humid climate around Knoxville, Tennessee, completed home energy retrofits in 2011. ORNL provided recommendations and collected metered data (e.g., submetered energy, temperature, humidity) at all homes after the retrofits were complete. The homeowners paid for the retrofits and ultimately decided what measures to complete and whether to take ORNL's advice. A year after the retrofit, the energy savings were calculated for all five homes and can be seen in Table 19.

Source energy savings range from 8 to $70 \%$ and correlate to the cost of the retrofit. Table 20 shows the cost-effectiveness of each retrofit. Notice that the net annual cost is positive for all homes; this means that none of the retrofits were cost-effective. Furthermore, the average simple payback for all homes is 43 years. A simple payback should be less than equipment lifetime ( 15 years) and less than the homeowner plans to stay in the home.

Table 19. Measured energy savings at Baker, Country and Summit. Modeled energy savings at Gaiter and Green.

\begin{tabular}{c|c|c|c|c} 
& Electric $(\mathbf{k W h})$ & Gas (therms) & Site (MMBtu) & Source (MMBtu) \\
\hline \hline Baker savings & $-21 \%$ & $61 \%$ & $32 \%$ & $8 \%$ \\
\hline Country savings & $33 \%$ & - & $33 \%$ & $33 \%$ \\
\hline Summit savings & $-19 \%$ & $86 \%$ & $61 \%$ & $33 \%$ \\
\hline Gaiter savings & $7 \%$ & $100 \%$ & $88 \%$ & $70 \%$ \\
\hline Green savings & $15 \%$ & $100 \%$ & $80 \%$ & $58 \%$
\end{tabular}

Table 20. Cost-effectiveness of each retrofit package

Cost of retrofit Energy bill savings

(\$)

\begin{tabular}{c|c|c|c|c}
\hline \hline Baker & 14,929 & 230 & 1,380 & 65 \\
\hline Country & 23,835 & 648 & 1,922 & 37 \\
\hline Summit & 52,698 & 770 & 4,914 & 68 \\
\hline Gaiter & 36,699 & 1,700 & 2,582 & 23 \\
\hline Green & 35,230 & 1,458 & 2,342 & 24
\end{tabular}

Figure 7 shows the site energy of each home normalized by the floor area compared to the national and southern average. Notice that Green and Gaiter are significantly higher than the other three homes and the national and southern averages. Both are historic homes with high infiltration and little or no insulation. The Green home was featured during the Knoxville, Tennessee World's Fair in 1982 as the energy efficient home, so even though the home is 100 years old, it had undergone some earlier energy retrofits. Although this study only involves 5 homes, Figure 7 indicates that homes can be retrofit with resulting energy consumption of less than half of the national average even when their pre-retrofit energy usage might have been 2 to 3 times that of the national average. 


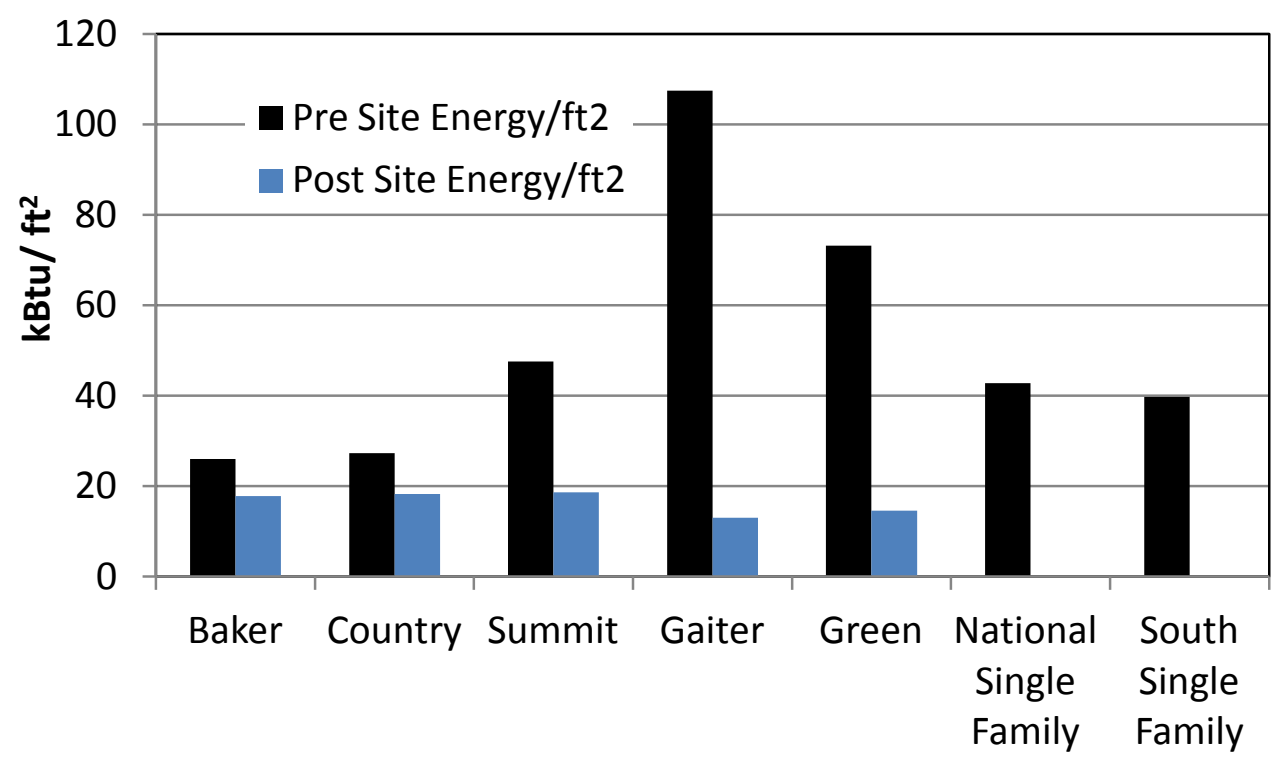

Fig. 7. Site energy normalized by floor area for all homes.

Although the energy and cost analysis adds to the body of knowledge concerning the high cost and long payback of residential energy retrofits, other lessons learned during this project can impact the residential retrofit market. The following lessons describe what ORNL learned about residential retrofits at a component level (e.g., ducts and sealed attics) and about the behavioral aspects of retrofits (comfort and retrofit timing). Some of these topics are covered in more detail in other reports.

\subsection{DUCT RETROFITS}

ORNL investigated duct retrofits at ten homes and found an average simple payback of 22 years with an average retrofit cost of $\$ 3,472$. The energy bill savings due to the duct retrofits ranged from 1.8 to $18.5 \%$. The retrofit costs were also found to be highly variable, with cost per square foot of conditioned space ranging from $\$ 0.92$ to $\$ 1.80 / \mathrm{ft}^{2}$. These duct retrofits included insulating and sealing the ducts with mastic and tape and sometimes replacing the entire duct system. It was found that because of the high cost of duct retrofits, energy savings is not the main deciding factor for pursuing these retrofits. The main drivers are increased comfort or health, or reduced carbon footprint. More information can be found in a previous report (Boudreaux, Christian, and Jackson 2012).

\subsection{SEALED ATTICS}

The attics at Green and Gaiter were sealed with spray foam on the roof deck and soffits, with no insulation on the attic floor. The Summit and Baker homes stayed with a traditional vented attic but increased the insulation on the attic floor to R-60 and R-38, respectively. The insulated roof deck keeps the attic air temperature closer to that of the conditioned space underneath the attic floor than does the vented attic.

To better understand heat flow in these two types of attics, simple calculations using the attic and conditioned space temperature and the thermal resistance of the attic floor assembly (insulation + drywall + framing members) were completed. Figure 8 shows the monthly heat flux between the attic and second floor for Summit, Baker, and Gaiter for each month of the monitored period. A positive heat flux 
indicates energy flowing from the attic to the conditioned space, and a negative heat flux indicates energy flowing from the conditioned space to the attic. Typically the heat flux at the attic plane is negative in the winter and positive in the summer. Notice that for most months, the heat transfer is greater for Gaiter, with a sealed attic, than for Baker and Summit, with vented attics. A similar phenomenon was found in analyzing the difference in heat flux between a vented versus a sealed crawlspace (Biswas, Christian, Gehl 2011). Even though the temperature difference between a sealed attic and living space is less than that between a vented attic and living space, the large thermal resistance of the attic floor insulation better restricts heat transfer across this plane in the vented attic scenario than in the sealed attic scenario. This confirms the idea that the sealed attic's main mode of energy savings is decreasing the energy loss from ducts that go through an attic (Rudd, Lstiburek, Ueno 2006). Energy transfer due to convection through the attic floor plane was not considered in this analysis.

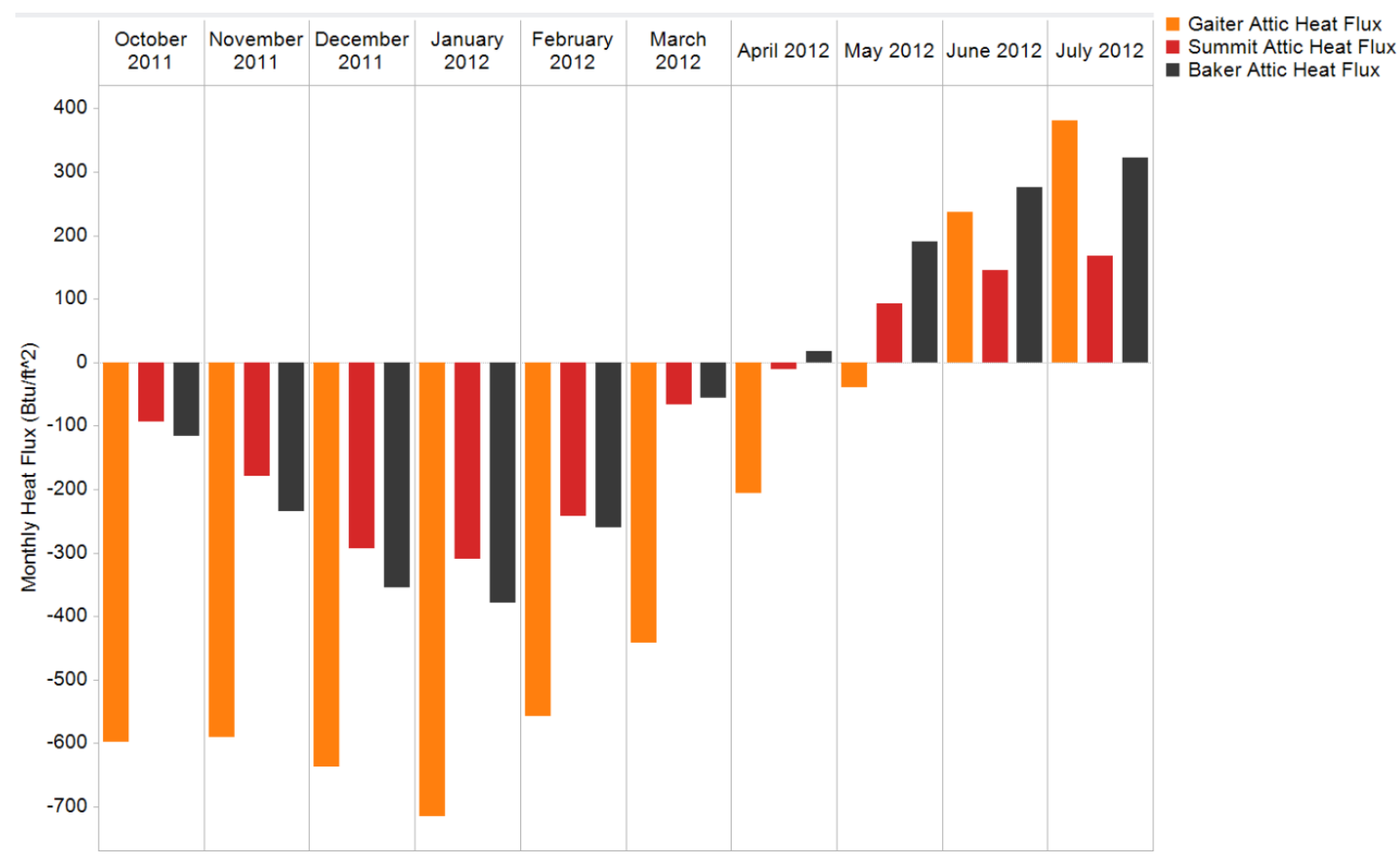

Fig. 8. Heat flux from attic to living space of sealed and vented attics. Sealed attics are Green and Gaiter; vented attics are Baker and Summit. A positive heat flux indicates energy flowing from the attic to the conditioned space, and a negative heat flux indicates energy flowing from the conditioned space to the attic.

\subsection{COMFORT}

ORNL learned that comfort is an important benefit and sometimes a motivator of energy retrofits. The Baker homeowner said increasing comfort was a main goal of the energy retrofit. A review of the homeowners' decisions found comfort to be an important aspect of energy retrofits for two other homeowners.

The Country homeowners brought the basement into the conditioned space a few years before the described energy retrofits were completed. The homeowners always felt that their 2.5 ton heat pump strained to keep the house comfortable after the basement was added. After the retrofits provided a tighter and better insulated home, ORNL recommended putting a high-efficiency 2.5 ton heat pump in the home. The homeowners wanted a Trane ${ }^{\circledR}$ unit, and the model they wanted came only in 2 or 3 tons. After looking again at the HVAC sizing software, ORNL felt the 2 ton unit would be sized properly. However, the homeowners chose a 3 ton unit for multiple reasons. They wanted to ensure the unit could provide the 
desired comfort; the unit was less expensive than competing brands that offered 2.5 ton units; and the unit offered more flexibility in the future if ventilation air were ever needed.

The Summit homeowners had 2 and 3 ton air conditioners in the home before the retrofit, a total of 5 tons of capacity. The homeowners decided to go with two Mitsubishi multi-split units with variable-capacity compressors so that they could have zone control of each room in the home. Eight indoor (evaporator/fan) units were installed in the home, with two outdoor condensers (each controlling four indoor units). Each outdoor unit had 3 tons of capacity, for a total of 6 tons. Because of the nature of this product, the options available to the homeowner were 4, 6, or 8 tons of capacity. Although ORNL recommended the 4 ton option, the homeowners chose the 6 ton option to ensure comfort.

These anecdotes show that nonenergy benefits of retrofits such as comfort should be considered in calculating the effectiveness of a retrofit. The hurdles come in attempting to incorporate comfort into the retrofit effectiveness methodology, because comfort information comes from subjective homeowner interviews.

\subsection{ENERGY RETROFITS DURING REMODELING OR REPAIRS}

All but one of these homeowners decided to complete energy retrofits after they decided to do major repairs due to water damage, or after deciding to do a major remodel/update of an old home. The Gaiter homeowner decided to research energy retrofits because inspection of the home revealed that the wiring and other components of the home would have to be brought to code, which required gutting the home. The Green home, built at the turn of the century, was also a gut remodel in which the architecture firm implemented energy-efficiency technologies. The Country and Summit homeowners both saw repairing extensive water damage as a good opportunity to complete energy retrofits.

These anecdotes should inform the building retrofit community that seizing the right opportunity for retrofits will help to decrease the cost. It is easier and cheaper to spray-foam the walls when the home is gutted for a remodel, than to remove the drywall to simply install insulation. Furthermore, as homeowners might update room-by-room, a long-term energy retrofit plan can be put in place. As the homeowners are ready to remodel a room, the plan can be followed to implement energy retrofits. This longer-term approach to retrofits may also save the homeowner money if the cost can be handled with cash rather than a loan. 


\section{REFERENCES}

Biswas, K., J. Christian, and A. Gehl 2011. Comparative Study of Vented vs. Unvented Crawlspaces in Identical Side-by-Side Homes in the Mixed-humid Climate, ORNL/TM-2011/438, Oak Ridge National Laboratory, Oak Ridge, Tennessee.

Boudreaux, P., Christian, J., and Jackson, R. 2011. Case Study of Duct Retrofits and Guidelines for Attic and Crawl Space Duct Sealing, ORNL-TM-2011/501, Oak Ridge National Laboratory, Oak Ridge, Tennessee.

Boudreaux, P., T. Hendrick, J. Christian, and R. Jackson 2012. Deep Residential Retrofits in East Tennessee, ORNL-TM-2012/109, Oak Ridge National Laboratory, Oak Ridge, Tennessee.

Energy Conservatory 2011. "Minneapolis Duct Blaster ${ }^{\circledR}$ Operation Manual," http://www.energyconservatory.com/sites/default/files/documents/duct_blaster_manual_series_b__dg700_revised.pdf (September 25).

EnergyGauge 2012. EnergyGauge Energy and Economic Analysis Software, http://www.energygauge.com/ (September 25).

IPMVP (International Performance Measurement and Verification Protocol) 2012. Concepts and Options for Determining Energy and Water Savings, Vol. 1, Efficiency Valuation Organization (January).

Kissock, J., J. Haberl, and D. Claridge 2003. "Inverse modeling toolkit: Numerical algorithms,” ASHRAE Transactions 109, Part 2, American Society of Heating, Refrigerating And Air-Conditioning Engineers.

Rudd, A. F., J. W. Lstiburek, and K. Ueno 2000. "UC attics: Where we've been and where we're going," in Proceedings of the 2000 ACEEE Summer Study on Energy Efficiency in Buildings, American Council for an Energy Efficient Economy, Washington, DC, August 23-28. 


\section{APPENDIX A}

\section{Pre-and Post-Retrofit Regressions}

Pre- and post-retrofit regressions for each fuel source at Baker, Country and Summit.

\begin{tabular}{|c|c|c|c|}
\hline Home & Fuel & Pre-retrofit (Daily) & Post-retrofit (Daily) \\
\hline \multirow[t]{2}{*}{ Baker } & Electric (kWh) & $\begin{array}{l}\text { If } O A T<59.7 \mathrm{~F}, \text { then } E=-0.799 \\
*(O A T-59.7)+23.9 \\
\text { If } 59.7<O A T<64.9, \text { then } E= \\
23.9 \\
\text { If } O A T>64.9, \text { then } E=2.64 * \\
(O A T-64.9)+23.9 \\
\mathrm{R}^{2}=0.935, C V-\mathrm{RMSE}=9.1 \%\end{array}$ & $\begin{array}{l}\text { If } O A T<58.8 \mathrm{~F}, \text { then } E=-0.459 * \\
(O A T-58.8)+38.3 \\
\text { If } 58.8<O A T<69.4, \text { then } E= \\
38.3 \\
\text { If } O A T>69.4, \text { then } E=1.67 * \\
(O A T-69.4)+38.3 \\
\mathrm{R}^{2}=0.624, \mathrm{CV}-\mathrm{RMSE}=11.9 \%\end{array}$ \\
\hline & Gas (therms) & $\begin{array}{l}\text { If } O A T<63.6 \mathrm{~F}, \text { then } E=-0.2 * \\
(O A T-63.6)+0.439 \\
\text { If } O A T>63.6, \text { then } E=0.439 \\
\mathrm{R}^{2}=0.981 \\
\text { CV-RMSE }=14.3 \%\end{array}$ & $\begin{array}{l}\text { If } O A T<50.5 \mathrm{~F}, \text { then } E=-0.172 * \\
(O A T-50.5)+0.637 \\
\text { If } O A T>50.5, \text { then } E=0.637 \mathrm{R}^{2}= \\
0.850, \\
\text { CV-RMSE }=38.3 \%\end{array}$ \\
\hline Country & Electric (kWh) & $\begin{array}{l}\text { If } O A T<51.9 \mathrm{~F}, \text { then } E=-2.26 * \\
(O A T-51.9)+42.0 \\
\text { If } 51.9<O A T<67.3, \text { then } E= \\
42.0 \\
\text { If } O A T>67.3, \text { then } E=1.09 * \\
(O A T-67.3)+42.0 \\
\mathrm{R}^{2}=0.921, \mathrm{CV}-\mathrm{RMSE}=7.6 \%\end{array}$ & $\begin{array}{l}\text { If } O A T<53.3 \mathrm{~F}, \text { then } E=-0.945 * \\
(O A T-53.3)+30.7 \\
\text { If } 53.3<O A T<66.9, \text { then } E= \\
30.7 \\
\text { If } O A T>66.9, \text { then } E=0.358 * \\
(O A T-66.9)+30.7 \\
\mathrm{R}^{2}=0.859, \mathrm{CV}-\mathrm{RMSE}=4.4 \%\end{array}$ \\
\hline \multirow[t]{2}{*}{ Summit } & Electric (kWh) & $\begin{array}{l}\text { If } O A T<68.6 \mathrm{~F}, \text { then } \\
E=19.9 \\
\text { If } O A T>68.6 \mathrm{~F}, \text { then } E=3.97 * \\
(O A T-68.6)+19.9 \\
\mathrm{R}^{2}=0.856 \\
\text { CV-RMSE }=18.2 \%\end{array}$ & $\begin{array}{l}\text { If } O A T<60.2 \mathrm{~F}, \text { then } E=-2.32 * \\
(O A T-60.2)+13.7 \\
\text { If } 60.2<O A T<69.5, \text { then } E= \\
13.7 \\
\text { If } O A T>69.5, \text { then } E=1.38 * \\
(O A T-69.5)+13.7 \\
\mathrm{R}^{2}=0.912, \mathrm{CV}-\mathrm{RMSE}=17.2 \%\end{array}$ \\
\hline & Gas (therms) & $\begin{array}{l}\text { If } O A T<62.6 \mathrm{~F} \text {, then } E=-0.263^{*} \\
(O A T-62.6)+0.685 \\
\text { If } O A T>62.6, \text { then } E=0.685 \\
\mathrm{R}^{2}=0.954 \\
\text { CV-RMSE }=18.3 \%\end{array}$ & No OAT correlation \\
\hline
\end{tabular}




\section{APPENDIX B \\ Energy Gauge ${ }^{\circledR}$ Modeling}

Because of a lack of data for the pre-retrofit condition of the Gaiter and Green houses, which had been unoccupied, the only way to estimate energy savings was to use a simulation tool. Therefore, EnergyGauge software was used to model the pre- and post-retrofit Gaiter and Green houses (EnergyGauge 2012). EnergyGauge uses the DOE 2.1-E hourly building energy simulation software to simulate energy use. The model calibrations were done using the available submetered post-retrofit energy usage measurements from the two houses. Typical meteorological year (TMY3) weather data were used in the EnergyGauge models. The weather-dependent measurements (whole-house consumption and space-conditioning load) were corrected for TMY3 weather data using the ASHRAE inverse modeling toolkit (Kissock, Haberl, and Claridge 2003).

First the post-retrofit model was created, using the post-retrofit building characteristics, and calibrated against measurements. The main parameters adjusted were the temperature settings and water usage to match the modeled heating and cooling and hot water loads to the measurements. The appliance, lighting, and miscellaneous energy annual consumptions were set to match the measurements. Once a calibrated post-retrofit model was developed that showed good agreement with the measured energy usage, it was archived and the model outputs were stored for comparison. The calibrated post-retrofit model was then converted to a pre-retrofit model by changing the characteristics of the envelope, space-conditioning and water heating equipment, appliances, and lights to the pre-retrofit conditions. The temperature settings and water usage profile were the same between the post- and pre-retrofit models.

Figures B.1 and B.2 show snapshots of the ceiling and walls inputs to the pre- and post-retrofit Gaiter house models. The geometries are identical, but the R-values reflect the different insulation levels in the two cases.

\begin{tabular}{|c|c|c|c|c|c|c|c|c|c|c|}
\hline \multicolumn{11}{|c|}{ CEILING } \\
\hline$\#$ & \multicolumn{3}{|c|}{ Celing Type } & R-Value & \multicolumn{2}{|c|}{ Area } & \multicolumn{2}{|c|}{ Framing Fraction } & \multicolumn{2}{|c|}{ Truss Type } \\
\hline $\begin{array}{l}1 \\
2 \\
\end{array}$ & \multicolumn{3}{|c|}{$\begin{array}{l}\text { Under Attic () } \\
\text { Cathedral/Single Assembly () }\end{array}$} & 0.1 & \multicolumn{2}{|c|}{$\begin{array}{l}795 \mathrm{ft}^{2} \\
178 \mathrm{ft}^{2}\end{array}$} & \multicolumn{2}{|l|}{$\begin{array}{l}0.11 \\
0.11\end{array}$} & \multicolumn{2}{|c|}{$\begin{array}{l}\text { Wood } \\
\text { Wood }\end{array}$} \\
\hline \multicolumn{11}{|c|}{$\begin{array}{c}\text { WALLS } \\
\text { Wall orientation below is as entered. Actual orientation is modifies }\end{array}$} \\
\hline \# & Omt & $\begin{array}{c}\text { Adjącent } \\
\text { To }\end{array}$ & Wall Type & $\begin{array}{l}\text { Cavity } \\
\text { R-Value }\end{array}$ & $\mathrm{Ft}^{\text {Width }}$ In & $\mathrm{Ft}_{\mathrm{In}}^{\text {Height }}$ & Area & $\begin{array}{l}\text { Sheathing } \\
\text { R-Value }\end{array}$ & $\begin{array}{l}\text { Framing } \\
\text { Fraction }\end{array}$ & $\begin{array}{c}\text { Solar } \\
\text { Absor. }\end{array}$ \\
\hline 1 & NW & Exterior & Frame - Wood & 0.1 & 8.5 & 9.68 & $82.28 \mathrm{ft}^{2}$ & & 0 & 0.75 \\
\hline 2 & NW & Exterior & Frame - Wood & 0.1 & 32.6 & 22 & $717.2 \mathrm{ft}^{2}$ & & 0 & 0.75 \\
\hline 3 & NW & Exterior & Face Brick - Block & 0.1 & 8.5 & 2.25 & $19.13 \mathrm{ft}^{2}$ & 0 & 0 & 0.75 \\
\hline 4 & SE & Exterior & Frame - Wood & 0.1 & 8.5 & 9.68 & $82.28 \mathrm{ft}^{2}$ & & 0 & 0.75 \\
\hline 5 & NW & Exterior & Face Brick - Block & 0.1 & 32.6 & 0.8 & $26.08 \mathrm{ft}^{2}$ & 0 & 0 & 0.75 \\
\hline 6 & SE & Exterior & Face Brick - Block & 0.1 & 8.5 & 6 & $51 \mathrm{ft}^{2}$ & 0 & 0 & 0.75 \\
\hline 7 & SW & Exterior & Frame - Wood & 0.1 & 22.18 & 14.31 & $317.4 \mathrm{ft}^{2}$ & & 0 & 0.75 \\
\hline 8 & SW & Exterior & Face Brick - Block & 0.1 & 22.18 & 6.2 & $137.52 \mathrm{ft}^{2}$ & 0 & 0 & 0.75 \\
\hline$\theta$ & SE & Exterior & Frame - Wood & 0.1 & 32.6 & 22 & $717.2 \mathrm{ft}^{2}$ & & 0 & 0.75 \\
\hline 10 & SE & Exterior & Face Brick - Block & 0.1 & 32.6 & 3.38 & $110.19 \mathrm{ft}^{2}$ & 0 & 0 & 0.75 \\
\hline 11 & SW & Exterior & Frame - Wood & 0.1 & 22.18 & 9.2 & $204.06 \mathrm{ft}^{2}$ & 0 & 0 & 0.75 \\
\hline 12 & NE & Exterior & Frame - Wood & 0.1 & 22.18 & 22 & $487.96 \mathrm{ft}^{2}$ & 0 & 0 & 0.75 \\
\hline
\end{tabular}

Fig. B.1. Snapshot of Gaiter pre-retrofit ceiling and wall inputs for the EnergyGauge model. 


\begin{tabular}{|c|c|c|c|c|c|c|c|c|c|c|}
\hline \multicolumn{11}{|c|}{ CEILING } \\
\hline$\#$ & \multicolumn{3}{|c|}{ Celling Type } & R-Value & \multicolumn{2}{|c|}{ Area } & \multicolumn{2}{|c|}{ Framing Fraction } & \multicolumn{2}{|c|}{ Truss Type } \\
\hline $\begin{array}{l}1 \\
2 \\
\end{array}$ & \multicolumn{3}{|c|}{$\begin{array}{l}\text { Under Attic } 0 \text {. } \\
\text { Cathedral/Single Assembly () }\end{array}$} & $\begin{array}{r}7 \\
24 \\
\end{array}$ & \multicolumn{2}{|c|}{$\begin{array}{l}795 \mathrm{ft}^{2} \\
178 \mathrm{ft}^{2} \\
\end{array}$} & \multicolumn{2}{|l|}{$\begin{array}{l}0.11 \\
0.11 \\
\end{array}$} & \multicolumn{2}{|c|}{$\begin{array}{l}\text { Wood } \\
\text { Wood }\end{array}$} \\
\hline \multicolumn{11}{|c|}{$\begin{array}{l}\text { WALLS } \\
\text { Wall orientation below is as entered. Actual orientation is modified }\end{array}$} \\
\hline$\#$ & Omt & $\begin{array}{c}\text { Adjącent } \\
\text { To } \\
\text {. }\end{array}$ & Wall Type & $\begin{array}{l}\text { Cavity } \\
\text { R-Value }\end{array}$ & $\mathrm{Ft}^{\text {Width }}$ In & $\underset{\mathrm{Ft}}{\mathrm{Ft}}{ }_{\mathrm{In}}^{\text {Height }}$ & Area & $\begin{array}{l}\text { Sheathing } \\
\text { R-Value }\end{array}$ & $\begin{array}{l}\text { Framing } \\
\text { Fraction }\end{array}$ & $\begin{array}{c}\text { Solar } \\
\text { Absor. }\end{array}$ \\
\hline 1 & NW & Exterior & Frame - Wood & 16 & 8.5 & 9.68 & $82.28 \mathrm{ft}^{2}$ & & 0 & 0.75 \\
\hline 2 & NW & Exterior & Frame - Wood & 16 & 32.6 & 22 & $717.2 \mathrm{ft}^{\mathrm{z}}$ & & 0 & 0.75 \\
\hline 3 & NW & Exterior & Face Brick - Block & 16 & 8.5 & 2.25 & $19.13 \mathrm{ft}^{\mathrm{z}}$ & 0 & 0 & 0.75 \\
\hline 4 & SE & Exterior & Frame - Wood & 16 & 8.5 & 9.68 & $82.28 \mathrm{ft}^{2}$ & & 0 & 0.75 \\
\hline 5 & NW & Exterior & Face Brick - Block & 16 & 32.6 & 0.8 & $26.08 \mathrm{ft}^{2}$ & 0 & 0 & 0.75 \\
\hline 6 & $\mathrm{SE}$ & Exterior & Face Brick - Block & 16 & 8.5 & 6 & $51 \mathrm{ft}^{2}$ & 0 & 0 & 0.75 \\
\hline 7 & SW & Exterior & Frame - Wood & 16 & 22.18 & 14.31 & $317.4 \mathrm{ft}^{\mathrm{z}}$ & & 0 & 0.75 \\
\hline 8 & SW & Exterior & Face Brick - Block & 16 & 22.18 & 6.2 & $137.52 \mathrm{ft}^{\mathrm{x}}$ & 0 & 0 & 0.75 \\
\hline$\theta$ & SE & Exterior & Frame - Wood & 16 & 32.6 & 22 & $717.2 \mathrm{ft}^{2}$ & & 0 & 0.75 \\
\hline 10 & SE & Exterior & Face Brick - Block & 16 & 32.6 & 3.38 & $110.19 \mathrm{ft}^{\mathrm{x}}$ & 0 & 0 & 0.75 \\
\hline 11 & SW & Exterior & Frame - Wood & 16 & 22.18 & 8.2 & $204.08 \mathrm{ft}^{\mathrm{x}}$ & 0 & 0 & 0.75 \\
\hline 12 & NE & Exterior & Frame - Wood & 16 & 22.18 & 22 & $487.96 \mathrm{ft}^{\mathrm{x}}$ & 0 & 0 & 0.75 \\
\hline
\end{tabular}

Fig. B.2. Snapshot of Gaiter post-retrofit ceiling and wall inputs for the EnergyGauge model.

Figures B.3 and B.4 show the infiltration, heating and cooling systems, and hot water systems used in the two models. The infiltration data were obtained using blower door tests of the Gaiter house.

\begin{tabular}{|c|c|c|c|c|c|c|c|c|c|c|c|}
\hline \multicolumn{12}{|c|}{ INFILTRATION \& VENTING } \\
\hline \multicolumn{2}{|c|}{ Method } & SLA & CFM 50 & ELA & EqLA & $\mathrm{ACH}$ & $\mathrm{ACH} 50$ & \multicolumn{2}{|c|}{$\begin{array}{cc}\text { - Forced Ventilation - } & \\
\text { Supply } \quad \text { Exhaust }\end{array}$} & Run Time & $\begin{array}{l}\text { Terrain/Wind } \\
\text { Shielding }\end{array}$ \\
\hline Teste & Single Point BD & 0.00142 & 6803 & 362.5 & 681.7 & 1.298 & 25.26 & 0 & 0 & 0 & Suburban / Suburban \\
\hline \multicolumn{12}{|c|}{ MASS } \\
\hline \multicolumn{3}{|c|}{ Mass Type } & \multicolumn{3}{|c|}{ Area } & \multicolumn{2}{|c|}{ Thickness } & \multicolumn{2}{|c|}{ Furniture Fraction } & & \\
\hline \multicolumn{3}{|c|}{ No Added Mass } & & $0 \mathrm{ft}^{2}$ & & & $\mathrm{ft}$ & 0.3 & & & \\
\hline \multicolumn{12}{|c|}{ COOLING SYSTEM } \\
\hline$\#$ & System Type & \multicolumn{3}{|c|}{ Subtype } & \multicolumn{3}{|c|}{ Efficiency } & Capacity & Air Flow & SHR & Ductless \\
\hline 1 & Central Unit & & None & & & \multicolumn{2}{|c|}{ SEER: 10} & $36 \mathrm{kBtu} / \mathrm{hr}$ & $1080 \mathrm{cfm}$ & 0.7 & False \\
\hline \multicolumn{12}{|c|}{ HEATING SYSTEM } \\
\hline \# & System Type & \multicolumn{3}{|c|}{ Subtype } & \multicolumn{3}{|c|}{ Efficiency } & Capacity & Ductless & & \\
\hline 1 & Natural Gas Furnac & & None & & \multicolumn{3}{|c|}{ AFUE: 0.75} & $98 \mathrm{kBtu} / \mathrm{hr}$ & False & & \\
\hline \multicolumn{12}{|c|}{ HOT WATER SYSTEM } \\
\hline$\#$ & System Type & & & $\mathrm{EF}$ & & Cap & & Use & SetPnt & & Credits \\
\hline 1 & Natural Gas & & & 0.54 & & $40 \mathrm{gal}$ & & $22 \mathrm{gal}$ & $120 \mathrm{deg}$ & & None \\
\hline
\end{tabular}

Fig. B.3. Snapshot of Gaiter pre-retrofit infiltration, space-conditioning, and hot water inputs for the EnergyGauge model. 


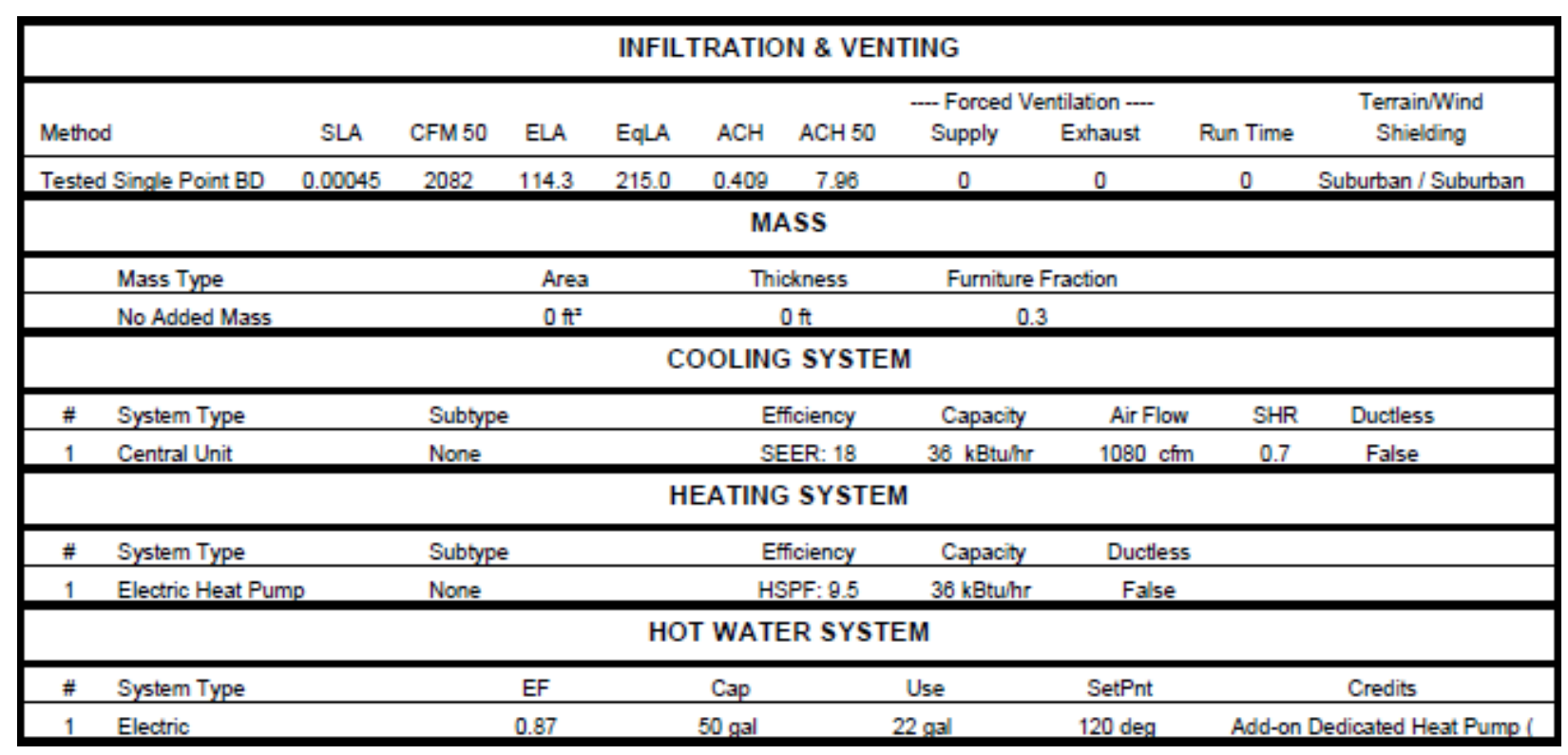

Fig. B.4. Snapshot of Gaiter post-retrofit infiltration, space-conditioning, and hot water inputs for the EnergyGauge model.

Figure B.5 shows the weekday (WD) and weekend (WEH) thermostat settings used for the Gaiter models. Identical temperature schedules were used for both the pre- and post-retrofit models.

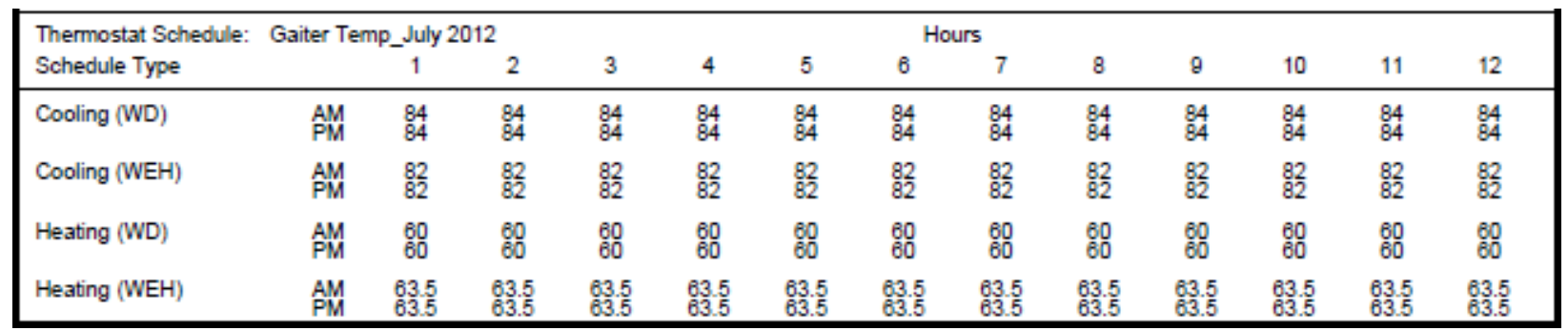

Fig. B.5. Temperature settings used in the Gaiter EnergyGauge models.

Figure B.6 shows the EnergyGauge modeled annual energy consumption of the pre- and post-retrofit Gaiter house. Also shown are the measured energy consumptions (Post-retrofit Energy Usage fit to TMY3 Data). The TMY3 weather corrections were applied to the space-conditioning and whole-house energy consumption. Under the measurements column, the total or sum of the individual end uses and the monitored whole house consumption are listed. The measured lighting and miscellaneous electrical loads were estimated from the measurements in individual rooms of the Gaiter house.

The modeled post-retrofit total energy consumption is in agreement with the TMY3 corrected wholehouse consumption within about $1 \%$. The modeled monthly energy consumption was compared to the TMY3 normalized measured energy and a CV-RMSE of $22 \%$ was found. The pre-retrofit house was equipped with a natural gas furnace for space and water heating. The modeled source energy savings due to the retrofit measures is $179 \mathrm{MBtu}$, or $70 \%$ of the pre-retrofit consumption. 


\begin{tabular}{|c|c|c|c|c|c|c|}
\hline \multicolumn{2}{|c|}{$\begin{array}{c}\text { Post-retrofit Energy Usage } \\
\text { fit to TMY3 Data }\end{array}$} & \multicolumn{2}{|c|}{$\begin{array}{c}\text { EnergyGauge Post-retrofit } \\
\text { Output }\end{array}$} & \multicolumn{3}{|c|}{ EnergyGauge Pre-retrofit Output } \\
\hline End-Use & kWh & End-Use & kWh & End-Use & $\mathrm{kWh}$ & Therm \\
\hline & & Cooling & 745 & Cooling & 3533 & \\
\hline & & Heating & 3846 & Heating & 964 & 1526 \\
\hline Heating + Cooling & 4555 & Heating + Cooling & 4591 & Heating + Cooling & 4497 & 1526 \\
\hline Hot Water & 784 & Hot Water & 796 & Hot Water & & 120 \\
\hline Hot Water Pump & 0 & Hot Water Pump & 0 & Hot Water Pump & & \\
\hline Total Hot Water & 784 & Total Hot Water & 796 & Total Hot Water & & 120 \\
\hline Washer & 14 & Washer & 15 & Washer & 15 & \\
\hline Dishwasher & 22 & Dishwasher & 22 & Dishwasher & 22 & \\
\hline Dryer & 211 & Dryer & 211 & Dryer & 211 & \\
\hline Lighting & 586 & Lighting & 592 & Lighting & 2023 & \\
\hline Misc. & 0 & Misc. & 0 & Misc. & 0 & \\
\hline Range & 5 & Range & 5 & Range & 5 & \\
\hline Refrigerator & 541 & Refrigerator & 541 & Refrigerator & 541 & \\
\hline Total $^{1}$ & 6718 & Total & 6773 & Total & 7314 & 1646 \\
\hline \multirow[t]{3}{*}{ Whole House ${ }^{2}$} & 6700 & & & & & \\
\hline & & Total Site (MBtu) & 23.1 & Total Site (MBtu) & 190 & \\
\hline & & Total Source (MBtu) & 77.2 & Total Source (MBtu) & 256 & \\
\hline
\end{tabular}

${ }^{1}$ Sum of the individual end-uses

${ }^{2}$ Measured whole house usage

Fig. B.6. Comparison of modeled pre- and post-retrofit Gaiter energy consumption using EnergyGauge; also shown are the measured energy consumptions regressed to outdoor air temperature using TMY3 data.

Figure B.7 shows the EnergyGauge modeled annual energy consumption of the pre- and post-retrofit Green house. The analysis procedure was similar to that used for the Gaiter house. Energy savings of $154 \mathrm{MBtu}$ were estimated by EnergyGauge models. The annual post-retrofit model total energy usage was within $10 \%$ of the weather-corrected whole-house energy measurements. The modeled monthly energy consumption was compared to the TMY3 normalized measured energy and a CV-RMSE of 10\% was found. 


\begin{tabular}{|c|c|c|c|c|c|c|}
\hline \multicolumn{2}{|c|}{$\begin{array}{c}\text { Post-retrofit Energy Usage } \\
\text { fit to TMY3 Data }\end{array}$} & \multicolumn{2}{|c|}{$\begin{array}{c}\text { EnergyGauge Post-retrofit } \\
\text { Output }\end{array}$} & \multicolumn{3}{|c|}{ EnergyGauge Pre-retrofit Output } \\
\hline End-Use & $\mathrm{kWh}$ & End-Use & $\mathrm{kWh}$ & End-Use & $\mathrm{kWh}$ & Therm \\
\hline & & Cooling & 983 & Cooling & 5616 & \\
\hline & & Heating & 3967 & Heating & 750 & 1174 \\
\hline Heating + Cooling & 4827 & Heating + Cooling & 4950 & Heating + Cooling & 6366 & 1174 \\
\hline Hot Water & 679 & Hot Water & 913 & Hot Water & & 117 \\
\hline Hot Water Pump & 501 & Hot Water Pump & 278 & Hot Water Pump & & \\
\hline Total Hot Water & 1180 & Total Hot Water & 1191 & Total Hot Water & & 117 \\
\hline Washer & 122 & Washer & 122 & Washer & 122 & \\
\hline Dishwasher & 36 & Dishwasher & 36 & Dishwasher & 36 & \\
\hline Dryer & 122 & Dryer & 122 & Dryer & 122 & \\
\hline Lighting & & Lighting & 1026 & Lighting & 2478 & \\
\hline Misc. & 2882 & Misc. & 1857 & Misc. & 1857 & \\
\hline Range & 63 & Range & 63 & Range & 63 & \\
\hline Refrigerator & 422 & Refrigerator & 422 & Refrigerator & 422 & \\
\hline Total $^{1}$ & 9653 & Total & 9789 & Total & 11466 & 1290 \\
\hline \multirow[t]{3}{*}{ Whole House ${ }^{2}$} & 10926 & & & & & \\
\hline & & Total Site (MBtu) & 33.4 & Total Site (MBtu) & 168 & \\
\hline & & Total Source (MBtu) & 112 & Total Source (MBtu) & 266 & \\
\hline
\end{tabular}

\footnotetext{
${ }^{1}$ Sum of the individual end-uses

${ }^{2}$ Measured whole house usage
}

Fig. B.7. Comparison of modeled pre- and post-retrofit Green energy consumption using EnergyGauge; also shown are the measured energy consumptions regressed to outdoor air temperature using TMY3 data.

To test the efficacy of the EnergyGauge model in estimating the energy savings of the retrofit measures, it was decided to model a house for which both pre- and post-retrofit data are available. The Summit house was chosen for this purpose. Again, a post-retrofit model was created and calibrated against the TMY3 corrected measurements and then converted to the pre-retrofit model by changing the building characteristics.

Figure B.8 shows the comparison of the pre- and post-retrofit model outputs and the post-retrofit measurements. First the pre-retrofit model was compared with the pre-retrofit utility bills to see how well EnergyGauge modeled the pre-retrofit condition of the home. The TMY3 corrected annual actual energy usage of the pre-retrofit Summit house was 12,526 kWh and 1,093 therms. The annual usage from the EnergyGauge model with pre-retrofit conditions was 11,208 kWh and 1,345 therms, a difference of $-10 \%$ and $+23 \%$, respectively, from the measured data.

Next, the energy savings calculated from this modeling procedure can be compared with the energy savings calculated from the gathered energy bills. Billing data showed a source energy savings of $48 \%$ or 104 MBtu of source energy savings. In comparison, the EnergyGauge models estimated a total energy saving of 53\% or $145 \mathrm{MBtu}$. Option D from IPMVP overestimated the percent source energy savings by 5 percentage points (IPMVP 2012). 


\begin{tabular}{|c|c|c|c|c|c|c|c|c|}
\hline \multicolumn{3}{|c|}{$\begin{array}{c}\text { Post-retrofit Energy Usage fit to } \\
\text { TMY3 Data } \\
\end{array}$} & \multicolumn{3}{|c|}{ EnergyGauge Post-retrofit Output } & \multicolumn{3}{|c|}{ EnergyGauge Pre-retrofit Output } \\
\hline End-Use & $\mathrm{kWh}$ & Therm & End-Use & $\mathrm{kWh}$ & Therm & End-Use & $\mathrm{kWh}$ & Therm \\
\hline & & & Cooling & 1781 & & Cooling & 4374 & \\
\hline & & & Heating & 5484 & & Heating & 868 & 1236 \\
\hline Heating + Cooling & 8338 & & Heating + Cooling & 7265 & & Heating + Cooling & 5242 & 1236 \\
\hline Hot Water & & 108 & Hot Water & & 108 & Hot Water & & 109 \\
\hline Hot Water Pump & & & Hot Water Pump & & & Hot Water Pump & & \\
\hline Total Hot Water & & 108 & Total Hot Water & & 108 & Total Hot Water & & 109 \\
\hline Washer & 57 & & Washer & 57 & & Washer & 107 & \\
\hline Dishwasher & 79 & & Dishwasher & 79 & & Dishwasher & 174 & \\
\hline Dryer & 502 & & Dryer & 502 & & Dryer & 892 & \\
\hline Lighting & 487 & & Lighting & 487 & & Lighting & 3063 & \\
\hline Misc. & 338 & & Misc. & 867 & & Misc. & 869 & \\
\hline Range & 88 & & Range & 88 & & Range & 84 & \\
\hline Refrigerator & 543 & & Refrigerator & 543 & & Refrigerator & 777 & \\
\hline Total $^{1}$ & 10432 & 108 & Total & 9888 & 108 & Total & 11208 & 1345 \\
\hline \multirow[t]{3}{*}{ Whole House ${ }^{2}$} & 10925 & & & & & & & \\
\hline & & & Total Site (MBtu) & 44.5 & & Total Site (MBtu) & 173 & \\
\hline & & & Total Source (MBtu) & 124 & & Total Source (MBt। & 269 & \\
\hline
\end{tabular}

${ }^{1}$ Sum of the individual end-uses

${ }^{2}$ Measured whole house usage

Fig. B.8. Comparison of modeled pre- and post-retrofit Summit energy consumption using Energy Gauge; also shown are the measured energy consumptions regressed to outdoor air temperature using TMY3 data. 